\title{
Animal Models of Depression: What Can They Teach Us about the Human Disease?
}

\author{
Maria Becker ${ }^{1} \mathbb{D}$, Albert Pinhasov ${ }^{2}$ and Asher Ornoy ${ }^{1,3, *}$ \\ 1 Adelson School of Medicine, Ariel University, Ariel 40700, Israel; mariabe@ariel.ac.il \\ 2 Department of Molecular Biology and Adelson School of Medicine, Ariel University, Ariel 40700, Israel; \\ albertpi@ariel.ac.il \\ 3 Hebrew University Hadassah Medical School, Jerusalem 9112102, Israel \\ * Correspondence: ashero@ariel.ac.il or ornoy@cc.huji.ac.il; Tel.: +972-2-6758-329
}

check for

updates

Citation: Becker, M.; Pinhasov, A.; Ornoy, A. Animal Models of

Depression: What Can They Teach Us about the Human Disease?

Diagnostics 2021, 11, 123.

https:/ / doi.org/10.3390/diagnostics 11010123

Received: 19 November 2020

Accepted: 8 January 2021

Published: 14 January 2021

Publisher's Note: MDPI stays neutral with regard to jurisdictional claims in published maps and institutional affiliations.

\section{Copyright: (C) 2021 by the authors.} Licensee MDPI, Basel, Switzerland. This article is an open access article distributed under the terms and conditions of the Creative Commons Attribution (CC BY) license (https:// creativecommons.org/licenses/by/ $4.0 /)$.

\begin{abstract}
Depression is apparently the most common psychiatric disease among the mood disorders affecting about $10 \%$ of the adult population. The etiology and pathogenesis of depression are still poorly understood. Hence, as for most human diseases, animal models can help us understand the pathogenesis of depression and, more importantly, may facilitate the search for therapy. In this review we first describe the more common tests used for the evaluation of depressive-like symptoms in rodents. Then we describe different models of depression and discuss their strengths and weaknesses. These models can be divided into several categories: genetic models, models induced by mental acute and chronic stressful situations caused by environmental manipulations (i.e., learned helplessness in rats/mice), models induced by changes in brain neuro-transmitters or by specific brain injuries and models induced by pharmacological tools. In spite of the fact that none of the models completely resembles human depression, most animal models are relevant since they mimic many of the features observed in the human situation and may serve as a powerful tool for the study of the etiology, pathogenesis and treatment of depression, especially since only few patients respond to acute treatment. Relevance increases by the fact that human depression also has different facets and many possible etiologies and therapies.
\end{abstract}

Keywords: depression; anxiety; animal models; behavioral tests; chronic and acute stress; social behavior

\section{Introduction}

Depression is probably the most common behavior-debilitating disease and is the most prevalent psychiatric disease among the mood disorders [1-4]. This widespread and chronic psychiatric illness can affect thought, mood and physical health causing serious disabilities. It is generally characterized by low mood, sadness, insomnia, lack of energy and no joy in life [5]. It is also a leading cause for suicidal attempts [6-8].

Depression affects up to $10 \%$ of the population and is about twice as common in women compared to men $[3,9,10]$. It may affect adolescents and adults and is more prevalent among elderly people $[3,11]$. Several medical conditions such as diabetes, chronic pain, cancer and emotional stress may increase the prevalence of depression [3,12] Depression is more common during pregnancy and post-delivery, affecting about $8 \%$ in the first trimester and $12-13 \%$ in the second and third trimester and in the peripartum period $[13,14]$.

The etiology of depression is still poorly understood. Genetic, epigenetic and environmental factors are apparently involved, with distinct changes in the hypothalamichypophyseal-adrenal axis [3,15]. Depression is characterized by monoamine synaptic imbalance [16,17]. Indeed, pharmacological treatment uses various drugs that raise the synaptic concentrations of serotonin or norepinephrine [18,19]. In spite of the fact that depression has important genetic elements, no specific genomic changes or polymorphisms can be directly linked to its etio-pathology [3,20,21]. Environmental factors such as stress, 
traumatic events and chronic pain seem to be important contributory factors [22]. It is therefore believed that depression results from the interaction of genetic and environmental factors $[3,16]$. Treatment is mainly based on modulation of brain monoamines by appropriate drugs and psychological support, especially Cognitive Behavioral Therapy (CBT). However, often treatment is ineffective, with aggravation of symptoms [23].

Depression and anxiety are highly comorbid [24], either occurring concomitantly or sequentially. Pharmacological treatment is often similar, as selective serotonin reuptake inhibitors (SSRIs) are effective for both problems, but sometimes different drugs or drug combinations must be used with emphasis on the disorder with the most severe symptoms. Depression and anxiety are also closely associated by sharing similar etiologies and genetic predisposition [25].

Like many other diseases, the understanding of the etiology and pathogenesis of depression can benefit from animal models. Moreover, appropriate animal models can also help in the search for effective treatment. Hence, genetic, epigenetic and environmentally induced animal models that reproduce symptoms typical to human depression have been developed, especially in rodents, to help the investigators better understand human depression. The purpose of the present review is to briefly discuss the more common animal models of depression and stress their strength and weakness.

\section{What Are We Looking for in Animal Models of Depression?}

Animal models may serve several purposes: first, they may enable a better understanding of scientific processes [26]. However, when evaluating animal data, it is important to remember that animals are not human beings, and many physiological and biochemical processes are different. Hence, when we evaluate the animal data we need to know how close is the etiology and pathogenesis in the animal model to that of the human disease and whether the measures of symptoms are reliable enough to resemble those of the human situation. This is especially important when we use neurobehavioral tools for measurement. Indeed, the modeling of depression in animals was initially based on the evaluation of abnormal social behavior, motivation, working memory, emotion, and executive functions.

Generally, animal models must meet three basic values: face validity, when animals recapitulate disease phenotype in a similar way to depressed humans; etiologic (construct) validity (relevance), when pathophysiological processes in animals are similar to those that cause a disease in humans; and predictive validity (pharmacologic sensitivity), when animals respond to medicines that are effective to treat depressed humans $[27,28]$. Unfortunately, many of the animal models of depression do not fulfill all these principles. Commonly, the construct validity in contemporary established animal models of depression is different from the real state of human depression because of the multiple intrinsic and extrinsic factors that may trigger the onset of depression and the fact that the exact pathophysiological mechanism still has to be elucidated. The requirements for animal models were revised, and additional validity criteria were introduced: homological validity; pathogenic validity; mechanistic validity; convergent validity; discriminant validity; internal and external validity $[29,30]$

Well-established animal models of depression were developed by applying different methodologic approaches, such as stressful factors or genetic manipulations, which triggered the appearance of depressive-like phenotype in rodents. Some animal models of depression were developed for testing the efficacy of newly developed antidepressant drugs or compounds. Some models, especially transgenic mice, serve to explore genetic and molecular pathogenic mechanisms. Similar to the situation in other animal models of human diseases, there seems to be no single animal model that can be used for all purposes of research on depression.

\section{Testing of Depression-Like Behavior in Animals}

The testing of behavior in rodents is usually based on the observation of certain behavior traits that can be considered analogous to the symptoms of depression in hu- 
mans [31-36]. Therefore, when describing animal models of depression, we use the description "depressive-like behavior". Symptoms of major depressive disorder (MDD) such as anhedonia and depressed mood, apathy, sleep disturbances, weight/appetite changes, psychomotor changes, and other comorbid conditions, such as anxiety and social isolation, may be easily evaluated in animals $[37,38]$. Other symptoms of depression in humans, such as feelings of sadness, guilt, or suicidal thoughts, cannot be simulated in rodents or other animal models.

\subsection{Evaluation of Despair-Like Behavior}

Feelings of despair or learned helplessness are modeled in rodents by placing an animal in an unpleasant, unescapable situation and evaluated by measuring certain behavioral traits by which the animal tries to escape that environment. The gold standards for despair testing are the Forced Swim Test (FST) [31], when the animal is placed in a water tank, and the Tail Suspension Test (TST) where the animal is suspended by its tail [32]. Initially, animals actively swim or struggle, and further, the animals begin to show periods of immobility, which then gradually increase. The increase in the immobility time is considered as depression-like behavior.

\subsection{Evaluation of Apathy-Like Behavior}

Apathy is considered a deficit in voluntary, goal-directed behavior [39]. In rodents, signs of apathy are manifested by impaired nest formation, unkempt hair due to impaired self-care, scanty maternal care, decreased social interest and decreased interest in novelty. These are considered as a depressive phenotype [37,40]. One of the ways to evaluate motivational and self-care behavior in rodents is a Splash-test [35,41]. The frequency and the duration of grooming are recorded during $5 \mathrm{~min}$ after sprinkling of $10 \%$ sucrose solution on the animals back coat, usually in its home cage. The viscosity of sucrose solution imitates dirt on the rodent fur and triggers grooming by licking or scratching. The delay in time between sprinkling and initiation of grooming and decreased frequency of grooming are considered as reduced motivational and self-care behaviors associated with depression-like phenotype.

\subsection{Evaluation of Anxiety-Like Behavior}

Anxiety commonly co-occurs with MDD and is evaluated in animals by studying the approach-avoidance conflict, the contradiction between their innate curiosity to explore a novel environment and their preference to be in closed/dark instead of open/illuminated places [42]. The commonly used test for anxiety evaluation is Elevated Plus Maze (EPM) or Zero Maze [33,43,44], where longer latencies to enter and/or shorter time spent in the open arms are interpreted as anxiety-like behavior. The open field test is another often used test, to assess both anxiety and locomotor activity [45]. The animal is placed in an open box, where its anxiety level is defined by the latency to enter and time spent in the center of the arena and the total traveled distance. These are taken as measures of locomotor activity. Anxiety may also be tested by novelty suppression of feeding (NSF) [46], conflict between the drive to eat food pellets in open/light space and the preference for closed/dark space [47]. The tree chamber test [48] for testing social interaction in rodents can also be used to measure level of anxiety.

\subsection{Evaluation of Anhedonia-Like Behavior}

Anhedonia means the loss of the ability to experience pleasure in things that previously seemed pleasant to a person. In rodents, anhedonia is usually expressed as a decreased preference for consumption of sweets (sucrose) [34], intracranial self-stimulation (ICSS) [49], preference for novel objects or situations, or frequency of sexual interactions [38]. 


\subsection{Evaluation of Impaired Cognitive Function}

Memory deficits and learning difficulties are often observed in depressive patients [50]. In rodents, cognitive behavior may be evaluated by the standard Morris Water Maze [51]. The ability of the rodent to learn to find a hidden platform beneath water reflects the rodent's hippocampal-dependent spatial memory and learning. Mice taking a longer time and a more complex trajectory of swimming path to find the platform are considered cognitively impaired with memory deficit. The Y-maze test is a widely used test for working and short-term memory. Two paradigms, spontaneous alternation and short-term memory, may be studied using the Y-maze, depending on the test-design protocol [52,53]. The percentage of spontaneous alternations is based on the frequency of complete alternations between the three arms.

\subsection{Evaluation of Social Interaction/Social Withdrawal}

Social withdrawal is one of the many symptoms in depressed patients [54] and may be easily measured in rodents by using the three-chamber paradigm test known as Crawley's sociability and preference for social novelty test $[36,55]$. This test is based on the spontaneous exploration by the mouse of any of the three chambers of the box, including indirect contact with one or two stranger mice. Sociability is defined as the preference to spend more time with a stranger, a different mouse, compared to the time spent in an empty chamber. This is recorded in a second session after the first habituation session. Mice spending less time near the stranger mouse are considered as having depression-like symptoms. However, social impairment is more obvious in mice with autism-like behavior, but can also be used to study depression-like behavior [56,57].

\section{Models of Depression}

As stated above, there are many different models of depression. The most widely used are environmentally induced and genetically based models. We will therefore discuss these different models at some length. Table 1 summarizes the different rodent models for depression, their strengths and weaknesses.

Table 1. Strengths and weakness of animal models of depression.

\begin{tabular}{|c|c|c|}
\hline Depression Models & Strengths & Weaknesses \\
\hline \multicolumn{3}{|c|}{ Environmentally induced Models of depression } \\
\hline Early-life stress & & \\
\hline Prenatal stress & $\begin{array}{l}\text { 1. Induce depression and anxiety-like phenotype: } \\
\text { prolonged immobility (despair-like behavior) } \\
\text { in FST and TST tests [58-60], anhedonia- } \\
\text { reduced preference to sucrose solution [58]. } \\
\text { and anxiety in EPM [58,61,62]. } \\
\text { 2. Induce changes along the } \\
\text { hypothalamic-pituitary-adrenal (HPA) } \\
\text { axis [60,63]. } \\
\text { 3. Useful in the research and elucidation of the } \\
\text { epigenetic mechanisms underlying the } \\
\text { consequences of gestational stress or early-life } \\
\text { stress to later depression and anxiety. }\end{array}$ & $\begin{array}{l}\text { 1. Differences in the rate and time of brain } \\
\text { ontogeny between rodents and } \\
\text { humans [64-66]. } \\
\text { 2. Predictive validity of antidepressant } \\
\text { treatment is uncertain. } \\
\text { 3. Difference in the rate and time of postnatal } \\
\text { brain development between rodents } \\
\text { and human }\end{array}$ \\
\hline
\end{tabular}


Table 1. Cont

\begin{tabular}{|c|c|c|}
\hline Depression Models & Strengths & Weaknesses \\
\hline Maternal separation & $\begin{array}{l}\text { 1. Induce learning and memory deficits [67]; } \\
\text { depressive- and anxious like behavior in open } \\
\text { field and EPM }[67,68] \text {. } \\
\text { 2. Induce changes along the } \\
\text { hypothalamic-pituitary-adrenal (HPA) } \\
\text { axis [69-71]. } \\
\text { 3. Induces long-lasting behavioral changes } \\
\text { until adulthood. } \\
\text { 4. Suitable for studying the interaction between } \\
\text { genes and environment in a newborn animal. }\end{array}$ & $\begin{array}{l}\text { 1. Long-lasting behavioral changes are } \\
\text { inconsistent due to different methodologies } \\
\text { among research groups [72], depending on } \\
\text { the mouse strain [73]; } \\
\text { 2. Using infant pups whose brain } \\
\text { developmental status corresponds to } \\
\text { prenatal human stage [64-66]. } \\
\text { 3. Poor predictive validity for antidepressant } \\
\text { treatment at adulthood [74]. }\end{array}$ \\
\hline $\begin{array}{l}\text { Post-weaning social } \\
\text { isolation stress }\end{array}$ & $\begin{array}{l}\text { 1. Induce depressive- and anxious-like behavior } \\
\text { in open field and EPM [75-81]. } \\
\text { 2. Demonstrated good predictive validity to } \\
\text { antidepressants treatment [82]. } \\
\text { 3. Useful to study the effects of social isolation } \\
\text { stressors on anxiety, depression and substance } \\
\text { use disorders (SUDs) in adolescence [83-86] }\end{array}$ & $\begin{array}{l}\text { It is rather a model of reward-associated } \\
\text { behaviors such as drug preference and } \\
\text { alcohol consumption in adulthood and } \\
\text { other varieties of psychiatric disorder, such } \\
\text { as schizophrenia and bipolar disorder } \\
{[76,81,85,87,88] \text {. }}\end{array}$ \\
\hline
\end{tabular}

2. Adulthood stress

1. Induces both anxiety- and depression-like behaviors in FST, TST EPM, and sucrose

Social isolation $\quad$ preference test [89-94].

2. Demonstrated good predictive validity to antidepressants treatment [93].

3. Induce changes in HPA $[92,93]$.
Study reports are inconsistent; isolation has strong strain-dependent and test-specific effects [95-97].

1. Induces anxiety- and depression-like behaviors with good similarity to the symptoms of depression with cognitive and neuroendocrine impairments [98,99].

Learned helplessness rats/mice.

(Acute stress)

2. Induces changes in HPA [100].

3. Useful to investigate the effect of unpredictable and uncontrollable stress.

4. Demonstrates good predictive validity for antidepressant treatment [101-103].

1. Induces both anxiety- and depression-like behaviors in FST, EPM, and sucrose preference tests [104-109].

Chronic mild stress 2. Demonstrates good predictive validity for (CMS) antidepressants treatment [110].

3. Induces changes in HPA [111].

4. Useful to investigate the effect of mild unpredictable stress.

1. Inconsistent response [100].

2. Short-term effect.

3. Weak etiologic validity because the exact role of the genetic construct of the stress-resilient and stress susceptible animal is as yet unknown
1. Induces depressive-like phenotype in social interaction, anhedonia, increased anxiety-like behavior, and impaired spatial learning [112-115].

Repeated restraint stress (CRS)
2. Demonstrates good predictive validity for antidepressants treatment $[112,116]$.

3. Induces changes in HPA [115].

4. Useful to explore the effect of chronic psycho-emotional stress [116-118].
1. Varied reproducibility of this model among different research centers [105].

\section{Induced short-term depression symptoms} tend to subside [112-115]. 
Table 1. Cont.

\begin{tabular}{|c|c|c|}
\hline Depression Models & Strengths & Weaknesses \\
\hline $\begin{array}{l}\text { Chronic social } \\
\text { defeat stress }\end{array}$ & $\begin{array}{l}\text { 1. Induces long-term depressive-like phenotype } \\
\text { expressed as anhedonia and social } \\
\text { avoidance [119-122]. } \\
\text { 2. } \begin{array}{l}\text { Demonstrates good predictive validity for } \\
\text { antidepressant treatment }[123,124] \text {. }\end{array} \\
\text { 3. Induces changes in HPA and dopaminergic } \\
\text { Ventral Tegmental Area (VTA) [122,125]. } \\
\text { 4. Useful to investigate the effect of repeated, } \\
\text { high-pressure social stress on depression. }\end{array}$ & $\begin{array}{l}\text { 1. Requires the use of a large number of } \\
\text { animals, takes up a lot of space in the } \\
\text { animal facility and is also quite } \\
\text { labor intensive. } \\
\text { 2. Requires to prevent significant damage to } \\
\text { the intruder mice to avoid ethical concerns. } \\
\text { 3. Cannot model female animals. }\end{array}$ \\
\hline
\end{tabular}

1. Induce both anxiety- and depression-like behaviors in OF, EPM, sucrose preference and social interaction tests [126-129].

Social instability stress 2. Demonstrates good predictive validity for (SIS) antidepressant treatment [126].

Inconsistent reports due to wide methodological variability among research groups [126].

3. Induces changes in HPA [126].

4. Useful to investigate the effect of repeated social stress on depression.

Lesions of the brain that may result in depression

1. Induces both anxiety- and depression-like behaviors in OF, EPM, sucrose preference, social interaction tests and memory dysfunction [130-140].

2. Demonstrates good predictive validity for

\section{Olfactory bulbectomy antidepressant treatment [133,135,141,142]} (OBX)

3. Induces changes in altered function of the noradrenergic, serotonergic, cholinergic, $\gamma$-aminobutyric acid, (GABA)ergic and glutamatergic neurotransmitter systems [130,143,144].

4. Useful in investigation of the chronic psychomotor agitated depression.
1. Injury to the olfactory bulbs cortex.

2. Mimics only a limited part symptoms of depressed patients.

\section{Pharmacological models}

Reserpine induced depression model

Corticosterone Model of Depression
1. Induces depression-like behaviors in OF, FST, TST and sucrose preference tests [145-148].

2. Demonstrates good predictive validity for antidepressant treatment [147,149-155].
1. Produces motor impairment mimicking Parkinson disease dyskinesia, increased nociceptive sensitization, hypothermia and has high rate of mortality [148,155-157].
1. Induces both anxiety- and depression-like behaviors in OF, EPM, sucrose preference, cognitive impairments in Morris water maze and T-maze tests [56,158-160].

2. Induces wide-range changes in stress-sensitive brain regions $[40,160]$.

3. Demonstrates good predictive validity for antidepressant treatment [161-163].

\section{Genetic models}

Wistar Kyoto

(WKY) model
1. Demonstrates depression-like behaviors in FST, OF, sucrose preference test [164-168].

2. Has innate HPA abnormalities [169-172].
1. Poor predictive validity for antidepressant treatment [173-175].

2. Exhibits significant differences in comparison to the human situation as it presents an abnormal HPA function [169-171]. 
Table 1. Cont.

\begin{tabular}{|c|c|c|}
\hline Depression Models & Strengths & Weaknesses \\
\hline $\begin{array}{l}\text { Genetically-selected } \\
\text { Flinders Sensitive Line } \\
\text { (FSL) rat model }\end{array}$ & $\begin{array}{l}\text { 1. Demonstrates depression-like behaviors in } \\
\text { 2. DST [176]. } \\
\text { Demonstrates good predictive validity for } \\
\text { antidepressants treatment }[177,178] \text {. } \\
\text { 3. Demonstrates changes in the cholinergic, } \\
\text { serotonergic, dopaminergic, neuropeptide Y, } \\
\text { and circadian rhythm systems and normal } \\
\text { HPA [177]. } \\
\text { Useful in studies of human depression with } \\
\text { psychomotor retardation and to evaluate } \\
\text { efficacy and safety of antidepressant agents in } \\
\text { pregnant dams and their offspring during } \\
\text { early life and later at adulthood [179] }\end{array}$ & $\begin{array}{l}\text { 1. There are many changes in different brain } \\
\text { neurotransmitters which are not } \\
\text { necessarily present in people } \\
\text { with depression. }\end{array}$ \\
\hline
\end{tabular}

1. Demonstrates both anxiety- and depression-like behaviors in OF, EPM, sucrose preference and social interactions tests,

Model of selective breeding for depressive-like (submissive) and manic-like (dominant) behavior in mice

Selective breeding model of low activity

in a swim test: high-active (SwHi) and low-active (SwLo) rats

object recognition tests [180-184].

2. Demonstrates good predictive validity for antidepressants treatment [180-182].

3. Demonstrates changes in stress-sensitive brain areas [184-186].

4. Useful to study social hierarchy effect on depression and in investigations of stress resilience and stress susceptibility.

1. Demonstrates both anxiety- and depression-like behaviors in FST, OF and EPM tests $[187,188]$.

2. Demonstrates good predictive validity for some antidepressants treatment [189].

3. Demonstrates changes in dopaminergic and
1. Selective breeding by

Dominance-Submissive Relationship (DSR) test resulted in strong augmentation and polarity of social phenotypic characteristics that may not necessarily be seen to such extent in the human population. glutamatergic pathways [190-192].

1. Demonstrates depressive-like phenotype with concomitant high voluntary ethanol intake [193,194].

The Fawn-Hooded (FH/Wjd) rat

2. Demonstrates good predictive validity for some antidepressant treatment [194].

3. Demonstrates changes serotonergic, GABAergic and HPA pathways [195-198].

It relays mainly on differences in locomotor activity and, therefore, has a low construct validity.

1. Association with the hemorrhagic disorder, known as platelet storage pool deficiency, that resemble Chediak-Higashi syndrome in humans [193] and therefore does not represent "pure" depression.

1. Uncertain face and predictive validity [199].

2. Conventional genetic deletion of genes results in lack and loss of functions throughout the body systems and induces impairments in many metabolic and system functions that are not necessarily seen to a similar extent in human depression.

3. Labor and cost intensive.

\subsection{Environmentally Induced Models of Depression}

The etiology of depression is primarily associated with acute and chronic stressful factors [200]. In some cases, acute or chronic stress leads to depression and other psychi- 
atric disorders, but not all individuals become depressed; some individuals are resilient to stress [201,202]. The precise mechanisms of resilience or susceptibility to stressors is far from being elucidated [202]. It seems, therefore, that genetic predisposition, adaptation pathways in brain circuits mediated by various neurotransmitters [203-205] and hormones [206], and the further response of individuals to stressful stimuli underlie successful coping with stress. It has been proposed that a dysfunction in the stress hormone, i.e., corticosterone regulation, is causally linked to depression $[207,208]$. Chronic and persistent stress impairs the hypothalamic-pituitary-adrenal axis, alters the immune system and induces various pathophysiological events detected in patients with depression [38].

Some established animal models will be described regarding applied stress factors (stressors). Early-life stress (prenatal stress, maternal separation, post-weaning social isolation), chronic-mild stress or social defeat stress models are the most validated and widely used models of depression, inducing a depression-like phenotype in experimental animals (Table 1).

\subsubsection{Early-Life Stress}

Early-life stress, when experienced during critical periods of development, such as prenatal, early postnatal and adolescence, may produce permanent changes to neural circuits with long-term negative sequelae $[209,210]$. Individual development (ontogenesis) of different parts of the brain occurs at different times during these periods, thus broadening the temporal window of vulnerability and the number of developmental processes [210-213].

\section{Prenatal Stress Modeling}

Maternal stress during pregnancy may affect offspring neurodevelopment and may lead to later appearance, at adulthood, of a psychiatric disorder, such as anxiety and depression [214-216]. Stress hormones, corticotropin-releasing hormone (CRH), catecholamines and glucocorticoids are transported via the placenta, reach, and affect the fetal brain [217]. Usually, gestational stress is induced daily by various stressors: combination of restraint, 24-h light disturbance, sleep deprivation, forced swimming or crowding in pregnant dams throughout gestation [58,218-220]. The prenatal stress paradigm causes the depression-like phenotype in rodents, demonstrating good face validity value. Prenatally stressed offspring show prolonged immobility in the FST test [59-61] and in the tail suspension test [58] as well as reduced preference to sucrose solution [58]. Prenatal stress also induces anxiety-like behavior in adolescent offspring measured by decreases in the time spent and number of entries in the open arm in the EPM test $[58,61,62]$. These changes were more pronounced in females than in males $[59,221]$. Prenatal stress paradigm has good construct validity: increased plasma corticosterone levels $[60,63]$, altered brain-derived neurotrophic factor (BDNF) transcripts and protein expression $[58,61]$ and morphological changes in dendritic complexity in the offspring hippocampus [218,222,223].

One important consideration for using this prenatal stress paradigm are differences in the rate and time of brain ontogeny between rodents and humans. These differences should be taken into consideration when translating the obtained results to the human situation [64-66] (Table 2).

Table 2. Timing differences in brain development in mice and rats compared to human.

\begin{tabular}{ccc}
\hline & Mice/Rats & Human \\
\hline Neural tube formation and closure [65,66] & GD *9-11 & GD 20-28 \\
Neurogenesis in the spinal cord and hindbrain structures [65,66] & GD 10 & week 4 of gestation \\
Organogenesis [65,66]. & GD 12-16 & Week 8-27 \\
Neurogenesis in the cerebellum and hippocampus. & First postnatal week-10 days & Late second and third trimester \\
cell migration, myelination, and synaptogenesis [65,66]. & PND ** 21-70 & 11-21 years \\
\hline
\end{tabular}

* Gestational Day. ** Postnatal Day. 


\section{Maternal Separation and Models of Early Life Stress}

Many studies on various species such as humans, nonhuman primates and rodents indicate that early adverse postpartum care (or stress at an early-life stage) increases the risk of depression in adulthood [224-228]. Maternal separation is one of the most studied animal models regarding the influence of early-life stress events on the development of depression later in adulthood [72]. The brain developmental status of rats and mice at the time of birth corresponds to that of the end of the second and early third trimester of the human fetus and is characterized by elevated synaptic plasticity, neurogenesis in the cerebellum and hippocampus and continued increase in the size of the cerebral hemispheres [64,66]. Bayer et al. [67] compared the developmental stages of the human fetal brain to that of the rat embryo and fetus and found, for example, that the development of the rat brain on day 21 before parturition is comparable to the human fetal brain in mid-pregnancy. Hence the early postnatal brain development in rats resembles that of the third trimester human fetus. Generally, the major phases of brain development in rodents and human are similar, but the timeline is drastically different. Similar brain developmental events last for days in rats and mice, and for weeks in humans [66].

Table 2 shows the prenatal and postnatal time differences in brain development between mice/rats and humans. The developmental stages in rats differ from those of mice in the range of 1-2 days.

The early postnatal period reflects a critical window of brain development, during which the brain is particularly vulnerable to harmful events such as stress [66]. Hence, mouse offspring during the early postnatal stage are highly dependent on maternal care. Early separation from the mother is highly stressful, influencing the development of the biological and behavioral phenotype of the offspring at adulthood. Usually, rodent pups are separated from their mothers for $3 \mathrm{~h}$ daily from the 2nd to the 12th postnatal day, modeling maternal neglect. Another approach to induce neonatal stress is limited nesting and bedding material in the cages, which models inappropriate maternal care. Later, upon reaching maturity, the animals' behavioral phenotype is evaluated. Generally, early maternal separation causes learning and memory deficits, depressive and anxiety-like behavior [67] in open field and elevated plus maze tests in either male or female mice [68], reflecting face validity. These behaviors were alleviated by fluoxetine pretreatment at adolescence, but not by chronic fluoxetine treatment at adulthood [74] in correspondence to predictive validity. Neonatal stress causes a decrease in BDNF, an increase in plasma corticosterone levels and a decrease in corticotrophin releasing factor (CRF) signaling pathways [69-71] demonstrating construct validity value.

However, this early stress effect inducing a depression-like phenotype is inconsistent $[30,40,72]$ and depends on the mouse strain [73]. In some studies, the opposite or no effect were also observed $[73,229,230]$. Tractenberg et al., in their systematic review of 94 mouse studies [72] commented that different methodologies of maternal separation were implemented in various studies, leading to variations in the degree of stress exposure for the pups and, later, to uncertain depressive-like behavior. The weakness of this model is the inconsistency of the long-term outcome following maternal separation and the dependence on the specific mouse strain. In addition, the relevance of using infant pups whose brain developmental status corresponds to a prenatal human stage is in doubt.

These depression-like animal models of prenatal and postnatal stress are highly useful in the research and elucidation of the epigenetic mechanisms underlying the consequences of gestational stress or early-life stress on later depression and anxiety. The understanding of the link between early-life aversion and the development of stress resilience or stress susceptibility may provide new insights into biological targets and in the development of new therapeutics for treatment or prevention of depression.

\section{Post-Weaning Social Isolation Stress}

Adolescence is initiated by central activation of the hypothalamic-pituitary-gonadal (HPG) axis resulting in stimulation of steroid hormone synthesis. These maturation pro- 
cesses, particularly judgmental or behavioral control, are accompanied by enormous sensitivity to social stress and rewarding stimuli [231]. Kessler et. al. [213,232] reported the high prevalence in the onset of mental disorders such as anxiety, depression, eating disorders and schizophrenia during adolescence.

Post-weaning social isolation (isolation rearing) in rodents is one of the most commonly investigated models of social isolation stressors as a risk factor for anxiety, depression and substance use disorders (SUDs) in adolescence, and later in adulthood (reviewed in [83-86,233]). Raising rodents in conditions of constant social isolation (SI) from weaning, depriving them of the opportunity for social play and disrupting the establishment of stable social hierarchies leads to behavioral changes influencing various psychiatric conditions such as depression, bipolar disorder and schizophrenia [27,76]. Usually, animals on post-natal days (PD) 21-28 are housed alone in a home-cage, maintained in social isolation for 3-8 weeks [234] and are not handled more than once a week (to change bedding material). However, isolated animals may have some visual, auditory, and olfactory contact with other isolated animals and those of their group-housed counterparts maintained in the same unit. Rats growing in post-weaning social isolation (SI-reared) develop an "isolation-induced stress syndrome" with excessive reactivity to handling, anxiety-like behavior and high emotionality $[75,235]$. Male and female SI-reared rats demonstrate good face validity of the depressive-like phenotype with increased motor locomotion [75-77] and decreased time spent in the arena center [78] in the open field test, and increased anxiety-like behaviors tested by the elevated plus maze [79-81]. These effects are irreversible by resocialization [236], as observed in males but not in females [237,238]. SI reared rodents demonstrated despair-like behavior expressed as increased immobility time in the FST [76,239] that was reversed by chronic fluoxetine treatment [82], indicating a good predictive validity. SI-reared rats exhibited apathy-like behavior expressed as diminished grooming time and frequency in the splash test [75], mainly in males. In addition, some studies showed that SI-reared rats, either male or female, demonstrated increased adult social interaction $[77,82,240]$.

SI-reared induced abnormal aggressive behaviors in male rats are tested by the resident-intruder test. This abnormal aggressiveness was named "behavioral fragmentation pattern" because of rapid fluctuations from one behavior to another, from abnormal attack to social interaction and to increased defensive upright, flight and freezing behaviors [241]. This abnormal aggressive behavior was attenuated by resocialization with concomitant chronic fluoxetine treatment [241]. Post-weaning SI paradigm also demonstrates good construct validity expressed as lower corticosteroid plasma levels [242,243], enhances synaptic plasticity of NMDAR-mediated glutamatergic transmission in the Ventral Tegmental Area (VTA) [244] and altered serotonergic and adrenergic systems [83,245] along a neuroaxis.

The weakness of this mode is that post-weaning SI, inducing long-lasting or even permanent depressive-like and anxiety-like behaviors, is rather considered as a model of reward-associated behaviors such as drug preference and alcohol consumption in adulthood schizophrenia and bipolar disorder [76,81,85,87,88].

When the social isolation stress paradigm is applied during adulthood it triggers in rodents both anxiety- and depression-like behaviors [89-94], evaluated by open field, EPM, FST, TST and anhedonia, expressed as reduced sucrose drinking and alterations in sexual reward behavior. Chronic fluoxetine treatment attenuated depressive-like behavior in the FST and TST in SI female mice but had no effect on anxiety-like behavior [93]. The altered behavior was accompanied by reduced plasma corticosteroids levels measured in SI adult mice [92,93], and lower expression levels of the BDNF and neuroplasticity-related genes in both hippocampus and prefrontal cortex [90]. It seems that the social isolation model of depression has good face, predictive and construct validity. However, the study reports are inconsistent and demonstrate strain-dependent and test-specific effects of depressive and anxiety-like behaviors [95-97]. 


\subsubsection{Adulthood Stress}

\section{Learned Helplessness in Rats/Mice (Acute Stress)}

The Learned Helplessness (LH) paradigm is widely used to explore the effect of unpredictable and uncontrollable stress applied during adulthood in rodents, who further develop an inability to cope with aversive but escapable situations. At the beginning this paradigm was used to induce depression-like phenotype in dogs [246] and was later adopted to rats [247-249] and mice [250]. LH paradigm is considered a model which manifests good similarity to the symptoms of depression, with construct and predictive validity, and cognitive and neuroendocrine impairments. In the learned helplessness paradigm, animals first receive several electric shocks on their feet in a closed chamber. Then, the subjects are placed in another chamber with a grid floor and receive a mild shock with the possibility of escape. Rodents that have not been previously exposed to the unescapable shock are commonly able to escape quickly from the shock, whereas animals previously exposed to the learned helplessness paradigm frequently fail to avoid shock $[248,251]$. This is considered as helplessness and indicates a depressive-like phenotype. Learned helplessness is reversed by antidepressant treatment [101-103]. These animals also demonstrate reduced weight, changes in locomotor activity (decreased locomotion or hyperactivity), sleep disturbances, decreased motivated behavior and anhedonia, but normal learning and memory [98,99]. Learned helplessness is associated with elevated glucocorticoid levels and reduced negative feedback responses of the hypothalamus-pituitary-adrenal (HPA) axis [100]. The learned helplessness paradigm causes an increase in pro-inflammatory cytokine levels, such as IL-1 $\beta$, IL-6, TNF- $\alpha$, INF- $\gamma$ and G-CSF in depressive-like animals [252,253].

This method of inducing depression-like behavior is not effective in all strains of rodents. The selective breeding of helpless lines from Harlan Sprague-Dawley outbred rats at State University of New York (SUNY) at Stony Brook SUNY, was developed as an effort to achieve a higher yield of helpless animals for learned helplessness following inescapable shock-training. Two variants were established: the congenitally learned helpless (cLH) rats exhibiting a helpless phenotype without exposure to uncontrollable shock, and a congenitally, not learned, helpless (cNLH) strain resistant to the effects of inescapable shock [100]. The weakness of this model is the inconsistent response to the above-mentioned stress and weak etiologic validity, because the exact role of the genetic construct of the responding animal is as yet unknown.

\section{Chronic Mild Stress (CMS)}

Willner et al. developed a paradigm of chronic mild stress (CMS), where different types of mild stressors are alternated [104,105]. CMS induced a depression-like phenotype with good face, construct and predictive validity. Usually, to induce CMS the animals are exposed for three weeks to a variety of long-term inescapable stressors, such as walking on ice, tube restraining, tail suspension, day and night reversal, tail clipping, and water or food deprivation which are performed every day randomly. Then, behavioral traits assessments are carried out. The most obvious feature of CMS that the animals manifest is anhedonia [106,107], demonstrated by sucrose intake and preference, which is reversed by chronic, but not by acute, antidepressant treatment [110]. Rodents exposed to CMS also exhibited hyperlocomotion in the open field test [107], shorter time spent in the open arm in EPM [108], and prolonged immobility time in the FST [109]. The CMS paradigm induces altered regulation of the hypothalamus-pituitary-adrenal (HPA) axis, changes in serotonergic, noradrenergic and dopaminergic systems, and reduced hippocampal BDNF level (details are reviewed by Hill et al.) [111]. However, the data on the depressive-like phenotype are inconsistent and the reproducibility of this model among different research centers varied [105]. Different studies used different methodologies and applied stressors, resulting in variations in the degree of stress on the mice and in undefined depressive behavior. 
Repeated Restraint Stress (CRS)

The CRS model also represents the depression model with good validity and is used widely in preclinical research to explore the effect of chronic psycho-emotional stress [116-118]. For chronic restraint stress, usually the animal is placed into a narrow cylindrical restrainer with a nose-hole for ventilation, in which it is unable to move, for $2-8 \mathrm{~h}$ daily for 21 consecutive days, followed by behavioral assessment. Rodents exposed to CRS exhibited the depressive-like phenotype in social interaction, anhedonia, increased anxiety and impaired spatial learning [112-115]. These behavioral features were attenuated by chronic treatment with fluoxetine. In addition, CRS triggered the elevation of serum corticosterone levels [115].

The weakness of CRS models lies in the fact that the induced short-term depression symptoms tend to subside.

\section{Chronic Social Defeat Stress}

Repeated social stress is the most common etiologic factor that triggers the development of depression in humans $[119,120]$. The social defeat stress animal model is based on the resident-intruder paradigm and simulates the pathogenesis of depression at the social level. Usually, for induction of mouse models of social defeat, ICR mice are used as the resident and $\mathrm{C} 57 \mathrm{Bl} / 6 \mathrm{~J}$ (B6) mice are used as the intruder which undergoes the physical and psychological stress [254]. Proven aggressive ICR mice are kept for several days in one compartment in the home cage, separated by a transparent acrylic wall, with small holes that allow the circulation of odors, pheromones and vocalizations. A B6 mouse is placed with an ICR mouse, and typically the ICR mouse attacks the B6 mouse (physical stress). After the attack, B6 is moved to a compartment adjacent to the ICR mouse and stays until the end of the day (psychological stress). On the next day, the B6 mouse is placed with another ICR mouse. Commonly, B6 mice are subjected to 10 daily sessions of physical and psychological stress. Interaction periods are recorded and later analyzed for aggressive, submissive, and exploratory behaviors by social interaction tests. This paradigm consistently yielded a subordinate/submissive phenotype of the intruder mouse in about two-thirds of involved animals. Stress-susceptible mice, experiencing repeated aggression, develop a long-lasting aversion to social contact, a deficit in sucrose preference and increased times of immobility in the FST and TST [121,122]. This may be reversed by enriched housing conditions [254-256] and by chronic, but not acute, administration of antidepressants [123,124], demonstrating a good predictive validity. The remaining one-third of animals are resilient to stress and fail to develop social avoidance or anhedonia. The social defeat stress animal model also has good construct validity, where alterations in HPA axis and dopaminergic ventral tegmental area (VTA) function were reported [122,125].

This social defeat model fits well with all the main demands of an animal model, demonstrating excellent etiological, face, and predictive validity [122]. However, this model requires the use of a large number of animals, takes up a lot of space in the animal facility and is also labor intensive. In addition, the social defeat stress imposes ethical concerns including the probability of skin damage to the experimental mouse (intruder), as a result of the attack of the aggressor mouse, which sometimes is a reason for further exclusion of the animal from the study. In addition, this model is pertinent mainly to male mice and to specific strains. As social defeat stress is not well adaptable to female rodents because they are less aggressive, the social instability stress (SIS) model was introduced for female animals [127].

Social instability stress is modulated in female rodents by changing the neighbor members within the cage, and by alternating periods of social isolation and crowding phases [126]. The social instability paradigm distorts the previously established social network and forces the animal to adopt to a new hierarchical rank in each of the crowding phases. Rodents that undergo this paradigm exhibit an anxiety and depressive like phenotype in open field, EPM and social interaction tests, and elevated peripheral corticosterone level [127-129] and lower hypothalamic glucocorticoid receptor (GR) expression [129]. The 
depressive-like behavior induced by the social instability paradigm is reversed by chronic antidepressant treatment with fluoxetine in both males and females [257]. This model mimics the male chronic social defeat stress model in many aspects, except for the gender differences and fewer ethical concerns.

\subsection{Lesions of the Brain that May Result in Depression Olfactory Bulbectomy (OBX)}

Anosmia or loss of odor discrimination is sometimes present in depressed patients $[258,259]$. This olfactory dysfunction may arise from the reduced volume of the olfactory bulb in depressed individuals [260]. The surgical ablation of olfactory bulbs in rodents is an appropriate depression model with reliable face, construct and predictive validity [130-132]. Bilateral olfactory bulbectomy (OBX) in rats is considered a model which represents chronic psychomotor agitated depression. It leads to the "irritable aggression" phenomenon, exhibited by increased attack, struggle, startled and fight responses in social interaction tests [133]. Bulbectomy in rats is followed by loss of odor and pheromone smell and the appearance of various abnormal behaviors such as anhedonia, memory dysfunction, sleep abnormalities and depression-like phenotype [130,134-136] which meet face validity. The most typical behavioral trait of OBX rats is hyper-locomotion in a brightly illuminated open field arena, due to paucity of opportunity to adapt to novelty. This hyperactivity is reversed by chronic, but not acute, antidepressant treatment [133]. In addition, OBX rats demonstrated decreased time spent in open arms in the elevated plus-maze [137,138], prolonged immobility time in the FST $[138,139]$ and reduction in sucrose intake in the sucrose preference test (SPT) [140]. OBX rats demonstrated impaired spatial learning and memory deficit in MWM, in the passive avoidance test, and in the 8-arm radial maze. These cognitive impairments are corrected by chronic SSRI treatment $[135,141,142]$. The abnormal, depressive-like behavioral traits in OBX rats feature altered function of the noradrenergic, serotonergic, cholinergic, GABAergic and glutamatergic neurotransmitter systems (reviewed in $[130,143,144]$ ), underlying construct validity.

Accumulation of Beta Amyloid has been observed in OBX rodents, and this model is therefore also applied to explore the molecular mechanism and drug efficiency of Alzheimer's disease (AD) [261,262].

The weakness of this model is the fact that it is produced by injury to the olfactory bulb cortex, mimics only a limited number of depressed patients and leads to significant cognitive impairment.

\subsection{Pharmacological Models}

\subsubsection{Reserpine Induced Depression Model}

Reserpine treatment in rodents induces depression-like behavior, that displays construct validity of monoamine dysfunction implicated in the development of depression. Reserpine is a vesicle reuptake inhibitor, which arrests the neurotransmitters (norepinephrine, epinephrine, dopamine and serotonin) reuptake process on the presynaptic membrane and, therefore, facilitates their further degradation by monoamine oxidase. The depletion of catecholamines (norepinephrine, epinephrine, and dopamine) and serotonin (5-HT) leads to morphological changes in the brain of tested animals and has good face validity due to the appearance of the depression-like phenotype [145-148,157]. This model is widely used in preclinical studies to evaluate the antidepressant effect of new developing drugs and plant compounds [149-154] due to the short-term time and good predictive validity [147,155]. However, reserpine treatment produces motor impairments mimicking Parkinson disease dyskinesia, increased nociceptive sensitization and hypothermia and has high mortality rate $[148,155-157]$.

\subsubsection{Corticosterone Model of Depression}

High levels of glucocorticoid administration mimics chronic stress. Corticosterone might be delivered to animals over a period of weeks to months by different methods: 
administered by subcutaneous injection, by pellet or osmotic pump implantation, or through the drinking water or food [160]. Chronic corticosterone treatment causes various behavioral abnormalities in rodents, such as increased immobility in the forced swim test, decreased grooming, impaired memory in MWM and T maze, anxiety-like behaviors in the open field and light/dark test, and anhedonia expressed by low sucrose preference $[40,56,158-160]$. Chronic treatment with fluoxetine [161,162], and an acute single dose of ketamine [163] reverse this corticosterone-induced depression-like phenotype.

Positron emission tomography with 18F-fluorodeoxyglucose ( $\{18 \mathrm{~F}\}$ FDG) in LongEvans rats chronically treated with corticosterone revealed decreased metabolic activity in the insular cortex and the striatum, but elevation in the cerebellum and midbrain [263]. Moreover, prolonged corticosteroids treatment led to structural changes in rodents' brains, such as reduced hippocampal volume and increased volume of amygdala (reviewed in [160]). Chronic corticosterone treatment may induce many metabolic and biochemical changes outside the brain, affecting animal behavior in a different way compared to human depression.

\subsection{Genetic Models of Depression}

\subsubsection{Wistar Kyoto (WKY) Model}

The Wistar-Kyoto (WKY) rat strain is considered a good animal model of endogenous depression. This rat strain was developed as a normal blood pressure control for the spontaneously hypertensive rat (SHR) by Okamoto and Aoki [171]. Besides normal blood pressure, WKY rats demonstrated hyper-reactivity to stress accompanied with disbalance of the hypothalamic-pituitary-adrenal (HPA) and hypothalamic-pituitary-thyroid (HPT) axes [169-171]. WKY rats developed depressive-like behavior in response to acute stress and chronic mild stress as measured by various behavioral tests, demonstrating good face construct and partial predictive validity. These rats demonstrated an increased immobility in the forced swim test (FST) $[164,165]$, decreased activity in the open field test $[166,167]$ and decreased consumption of a sugar-based solution (enhanced anhedonia) [168]. Depressive-like behavior of WKY rats was slightly attenuated by treatment with tricyclic antidepressants (TCA) $[173,174]$, but was resistant to Fluoxetine, a selective serotonin reuptake inhibitor (SSRI) [175].

WKY rats exhibit altered endogenous brain neurotransmitters, including abnormalities of the monoaminergic, dopaminergic and noradrenergic neurotransmitter systems and thyroid-stimulating hormone systems. The main critical feature of this animal model is HPA dysfunction, manifested by higher plasma content of anterior pituitary adrenocorticotropic hormone (ACTH) [172], decreased levels of serum corticosterone, TNF- $\alpha$, IL-1 $\beta$, increased IL-10 [264], and down-regulated glucocorticoid receptors (GR) in the hippocampus. Hence, this model exhibits significant differences in comparison to the human situation as it presents an abnormal HPA and HPT functions.

\subsubsection{Genetically Selected Flinders Sensitive Line (FSL) Rat Model}

Flinders Sensitive Line (FSL) and Flinders Resistant Line (FRL) rats were bred from Sprague-Dawley (SPD) rats at Flinders University in Australia. They produced strains with increased (FSL) or decreased (FRL) sensitivity to the cholinesterase inhibitor, an organophosphate anticholinesterase agent, diisopropyl fluorophosphate (DFP) [265]. FSL rats have higher levels of muscarinic receptors in the striatum and hippocampus compared to FRL rats [266], which undelay their sensitivity to cholinesterase inhibitors. Similarly, depressed humans are more sensitive to cholinergic agonists [267]. This line of rats exhibits behavioral features characteristic of depression, and respond to chronic, but not acute, antidepressant treatment $[177,178]$, with good predictive validity. The FSL rats have been proposed as a rat model of human depression with psychomotor retardation, because they are hypoactive in open field and exhibit prominent immobility in the forced swim test [176] reflecting good face validity. FSL rats also exhibit reduced appetite and psychomotor dysfunction, sleep and immune abnormalities, but preserve normal hedonic state and 
cognitive function $[177,268]$. FSL rats have good construct validity as neurochemical and/or pharmacological studies demonstrated changes in the cholinergic, serotonergic, dopaminergic, NPY, and circadian rhythm systems, with normal functions of noradrenergic, HPA axis and GABAergic systems [177]. FSL exhibit anhedonia only when exposed to chronic mild stress [269], implying the potency of this model to elucidate the impact of environmental factors and gene predisposition in MDD pathogenesis.

This genetic model of endogenous depression represents good validity and serves not only to investigate the pathogenic mechanisms that underlie the morbidity of MDD but is also an appropriate model to evaluate the efficacy and safety of antidepressant agents in pregnant DAMs and their offspring during early life and later adulthood [179]. The main weakness of this model lies in the fact that there are many changes in different brain neurotransmitters which are not necessarily present in people with depression.

\subsubsection{Model of Selective Breeding for Depressive-Like (Submissive) and Manic-Like} (Dominant) Behavior in Mice

A mouse model demonstrating strong and stable inheritable features of dominance and submissiveness was successfully established at Ariel University in Israel $[185,270]$. The populations of dominant (Dom) and submissive (Sub) mice were raised from the outbred Sabra strain, selectively bred for 48 generations based on the food competition Dominance Submissive Relationship (DSR) paradigm. The Sabra strain's behavioral and biochemical characteristics lie within the diapason of those of C57BL/6, Balb/c and ICR mice [271]. The behavioral phenotypes of Dom and Sub mice were cross-validated in different behavioral tests including forced swim test (FST), resident-intruder test (RIT), three chamber test (TChT), and sucrose preference test and all show good face validity. These Dom and Sub mice react differentially to antidepressants, mood stabilizers and psychotropic agents and their inherited behavioral tendencies are dependent upon environmental and social triggers [180-182]. Paroxetine showed dose dependent anti-depressive-like effect in Sub mice and caused a paradoxical effect in Dom mice. Sub mice serve as an animal model of depression demonstrating depressive-like behavior and are susceptible to stressful stimuli, whereas Dom mice exhibit strong characteristics of manic-like behavior and show pronounced stress resilience $[180,183]$. The altered monoamine content in brain areas referring to emotionality and social hierarchy underly the behavioral phenotype in Sub and Dom mice. The decreased levels of 5-HT in the brainstem, reduced levels of norepinephrine in the prefrontal cortex and hippocampus, and elevated levels of dopamine in the prefrontal cortex, HPC, striatum and brainstem were measured in Sub mice [186].

Three-months adult Sub mice demonstrated impaired cognitive behavior, evaluated by 8 -arm radial maze and by novel recognition test, with further deterioration in memory at 9 months [184]. This impairment in memory formation in Sub mice was correlated to abnormal overexpression of $\alpha$-amino-3-hydroxy-5-methyl-4-isoxazolepropionic acid (AMPA) receptor and higher density of glutamate A1 (GluA1) in the hippocampus [184]. Transcriptomic analysis revealed differential hippocampal expression of genes involved in synaptic plasticity including Syn IIb isoform of SynapsinII gene, BDNF and IGF-1, which were significantly lower among Sub mice, in comparison to both Dom and wild type (WT) counterparts $[184,185]$.

Proteomics analysis of hippocampal formation of Dom and Sub mice demonstrated expression changes in protein datasets responsible for social interaction. Among the most enriched categories, extensive changes were found in proteins related to presynaptic release, ion channel regulation, circadian rhythm, mitogen-activated protein kinase (MAPK), ErbB and NF-kB pathways [272].

Recent studies revealed that the innate stress susceptibility of Sub mice is reflected in significant reduction in the lifespan of both male and female. Shortened lifespan of Sub correlated with chronic inflammation, age-dependent splenomegaly and a significant increase in the circulating levels of IGF- 1 and pro-inflammatory cytokines IL- $1 \beta$ and IL-6 [273]. 
The Dom and Sub mice fit well all the main demands of an animal model, demonstrating excellent etiological, face and predictive validity. The weakness of this model is that selective breeding resulted in strong augmentation and polarity of social phenotypic characteristics that may not necessarily be seen to such an extent in the human population.

4.4.4. Selective Breeding Model of Low Activity in a Swim Test: High-Active (SwHi) and Low-Active (SwLo) Rats

Sprague-Dawley (SD) albino rats were selectively bred based on the swimming motor activity in the forced swim test. This breeding for at least 45 generations resulted in the development of two rat lines; Swim Low-Active (SwLo) and Swim High-Active (SwHi) rats [187]. SwLo rats demonstrated shorter struggling time and increased immobility phase, corresponding to depression-like behavior in rodents as feelings of despair. SwHi rats exhibited an opposite response: increased struggling time and shorter immobility time. Chronic, but not acute antidepressant treatment, reverses this depressive-like phenotype in SwLo rats [187]. Several chronically administered tricyclic antidepressants, such as imipramine, desipramine, venlafaxine, phenelzine and bupropion, efficiently prolonged the struggling time of SwLo rats in FST [189], but SSRIs were not effective. Both SwLo and SwHi rats exhibited similar locomotion activity tested by open field, and almost equal time spent in the open arm in the EPM study [188]. Therefore, SwLo rats rather represent the model of atypical depression [274]. It was suggested that depression-like behavior of SwLo rats in the swim test results from alteration in dopaminergic $[190,191]$ and glutamatergic pathways [192]. This model has good face, etiological and predictive validity. Its weakness is that it relies mainly on differences in locomotor activity and therefore has a low construct validity.

\subsubsection{The Fawn-Hooded (FH/Wjd) Rat}

Fawn-Hooded (FH/Wjd) rats are an inbred strain with abnormal serotonin storage in the platelets. Fawn-Hooded rats are associated with the hemorrhagic disorder, known as platelet storage pool deficiency, that resembles Chediak-Higashi syndrome in humans [193]. $\mathrm{FH} / \mathrm{Wjd}$ rats exhibit a depressive-like phenotype with concomitant high voluntary ethanol intake and show good face validity as an animal model of depression, comorbid with alcoholism. These rats have low motor activity and increased immobility time in the forced swim test, accompanied by an elevated basal level of corticosterone. These features are reversed by chronic treatment with SSRIs $[193,194]$. Chronic fluoxetine treatment attenuates the immobility of FH/Wjd rats but does not affect alcohol intake [194]. Regarding construct validity, $\mathrm{FH} / \mathrm{Wjd}$ rats exhibit abnormalities in function of the central serotonergic, GABAergic and HPA pathways [195-198].

\subsection{Genetic Manipulation Induced Models of Depression}

Mouse genetic models have played an important role in the elucidation of molecular pathways underlying human disease. The sequencing of the mouse genome revealed $90 \%$ gene homology to the human genome, with $80 \%$ identity among the protein-coding regions [275]. A widely used method to determine the function of a gene suspected of causation of a certain disorder, such as depression, is to delete the gene from the investigated organism (usually mice) by homologous recombination. Using null mutants or knockouts for that specific gene allows the investigation of the effect and the role of the absence of the specific gene (and the protein that it encodes) in the pathogenesis of certain diseases (such as depression). Another conventional strategy for gene modification, opposite to the development of knockout models, is transgenesis, when a foreign gene (i.e., human transgene or mutated gene) is introduced into a recipient organism's genome, creating a transgenic animal.

Family-based studies in humans suggest about $40 \%$ of familiar heritability for depression [276]. Hence, genetic animal models may also help to better understand the role of heritability in depression. Genetic rodent models may provide proof of concept of the involvement of specific genes in depression pathophysiology. 
Several molecular mechanisms were discovered to play a role in the pathogenesis of depression: among them are monoamine neurotransmitters such as serotonin [18,277-279], noradrenalin [18,280,281] and dopamine [282-284], and enzymes involved in their degradation (monoamine oxidase) or precursors of their synthesis (tryptophan) $[279,281,282]$. The most investigated genes are BDNF [17], serotonin receptor (5-HT) [285] and Sirt1 [286,287]. These genes regulate pathways that are implicated in the development of mood disorders; BDNF regulates neural plasticity and connectivity generally via tyrosine receptor kinase $B$ (TrkB), and 5-HT, SLC6A4 and COMT are involved in the regulation of neurotransmitter signaling. The meta-analyses of genome-wide association studies (GWAS) suggested that FBXL4 (F-box and leucine rich repeat protein 4) and RSRC1 (Arginine and Serine Rich Coiled-Coil 1 or SRrp53) may play a role in MDD [288]. Additional genome-wide association data found that cAMP-specific $3^{\prime}, 5^{\prime}$-cyclic phosphodiesterase 4B (PDE4B) enzyme gene variants are associated with anxiety and stress-related disorders [289].

Based on the monoamine hypothesis of depression, the role of BDNF and genes involved in the HPA axis regulation, several models of knock-out/knock-in mice were generated (for detailed review see $[199,290]$ ). Here, we briefly describe some of the most commonly investigated genetically generated mice lines. The majority of these lines involve the inactivation of a candidate gene for depression, resulting in an anti-depressive-like phenotype. The deletions of the norepinephrine transporter, (NET-KO) mice demonstrated a stress resilience phenotype to restrained stress or social defeat [291]. The lack of 5-HT reuptake in SERT-KO mice causes the development of the phenotype that resembles the acute effects of selective serotonin reuptake inhibitor (SSRI) treatment, including increased anxiety, or even the serotonergic syndrome which is characterized by spontaneous dorsiflexion of the tail (Straub tail), tics, tremor and backward gait [292-295]. DAT-KO mice with dopamine transporter deletion developed depressive-like symptoms but have pronounced spontaneous hyperlocomotion [296,297] and mimic the effects of long-term exposure to psychostimulants. DAT-KO mice are, rather, a model of attention-deficit/hyperactivity disorder (ADHD), and their hyperlocomotion behavior was attenuated by treatment with Methylphenidate $[298,299]$. Increased expression of the 5-HT transporter in mice led to a low-anxiety phenotype [300]. Interestingly, mice with glutamate receptor gene GRIK4 deletion have reduced anxiety and an antidepressant-like phenotype [301]. Similarly, genetic deletion of the NMDA receptor NR2A subunit also results in decreased anxiety-like and depression-like behaviors [300]. Neurotrophic homozygous genetic models with deletion of BDNF and TRKB receptor are not viable [302-304], whereas heterozygous BDNF and TRKB receptor KO mice did not demonstrate differences from normal animals [305-307].

Genetic manipulation based on alterations of the HPA axis also provide a great opportunity to explore the molecular basis of the HPA axis in depression. Corticotropin-releasing factor (CRF) overexpression in mice results in increased anxiety-like behavior [308], but not depressive-like behavior [309]. Homozygous CRF knockout mice, despite being viable, do not demonstrate behavioral abnormalities compared to control littermates [310].

The use of Cre-driver mouse lines for targeting local specific brain areas associated with depression and emotionality such as forebrain, hippocampus and VTA, provides a new approach to investigate proof of concept as to how the brain modulates mood and mood disorders [311,312]. Within the development of Clustered Regularly Interspaced Short Palindromic Repeats (CRISPR)-associated protein 9 (Cas9) system (CRISPR/Cas9) technology, the new generation of $\mathrm{KO}$ mice were developed in order to investigate the role of specific proteins on depression-like phenotype development and for further translation to clinical depression [313-315].

Using genetically engineered mice provides an excellent platform to prove the concept of gain in function or loss of function of a specific gene. However, the generated line demonstrated an uncertain face and predictive validity $[199,290]$. Depression is a multifactorial disease underlined by multiple genes, and, therefore, single gene deletion or overexpression cannot overlap all depression core symptoms $[199,290]$. Conventional genetic deletion of genes results in spreading lack and loss of function throughout the body 
systems and induces impairments in many metabolic and system functions that are not necessarily seen to such an extent in human depression. The generation of knock-in or knock-out mice is also labor and cost intensive.

\subsection{Is There an Ideal Animal Model of Depression?}

The above described rodent models of depression indeed mimic many aspects of human MDD but none of them is "the ideal model". Models in primates are generally closer to the human situation as the animals show similar symptomatology and often share a similar etiology [316-318]. Indeed, several models were developed in monkeys that might better fit the concept of an ideal model of a human disease. For example, Hennessy et al. showed that social isolation in male rhesus monkeys induced within several weeks a depressive-like posture and behavior in up to $90 \%$ of these monkeys [317]. A naturally occurring depression similar to that in humans was also described by $\mathrm{Xu}$ et al. in colonies of cynhomologous monkeys [318]. Hence, there seems to be an advantage in the use of monkeys as models that mimic human MDD. However, since it is not easy to establish primate colonies for such studies, the concomitant use of several rodent models, each one with its strengths and weakness, may overcome the lack of a single ideal model.

\section{Conclusions}

We described the more common models of depressive-like behavior in rodents. The fact that different facets of depressive-like behavior can be induced by genetic, environmental, surgical or pharmacologic means emphasizes the complexity of depression. It is generally observed that these models affect different brain neurotransmitters, further demonstrating that depression is not just an imbalance between monoamine neurotransmitters. While there is no single model that mimics all aspects of the human disease, the concomitant use of several of these animal models may be sufficient to cover all the different aspects of depression. As for future directions, there is still a need to develop a non-primate model that will resemble human depression in all aspects: etiology, pathogenesis treatment and prevention. Such a model must take into consideration the multiple etiologies of depression, the variety of clinical presentations and the fact that, often, current treatment modalities are ineffective. We are in particular need of models where we will be able to test exploratory treatment methods to enrich effective therapy. We should not forget, however, that the ultimate testing is in humans.

Author Contributions: A.O. wrote the introduction, description of depression and conclusions, M.B. described all available models and prepared the tables, A.P. wrote the paragraph that referred to selective breeding of submissive and dominant mice, established in his laboratory. All authors have read and agreed to the published version of the manuscript.

Funding: This research received no external funding.

Conflicts of Interest: None of the authors has any conflict of interest in the preparation of this.

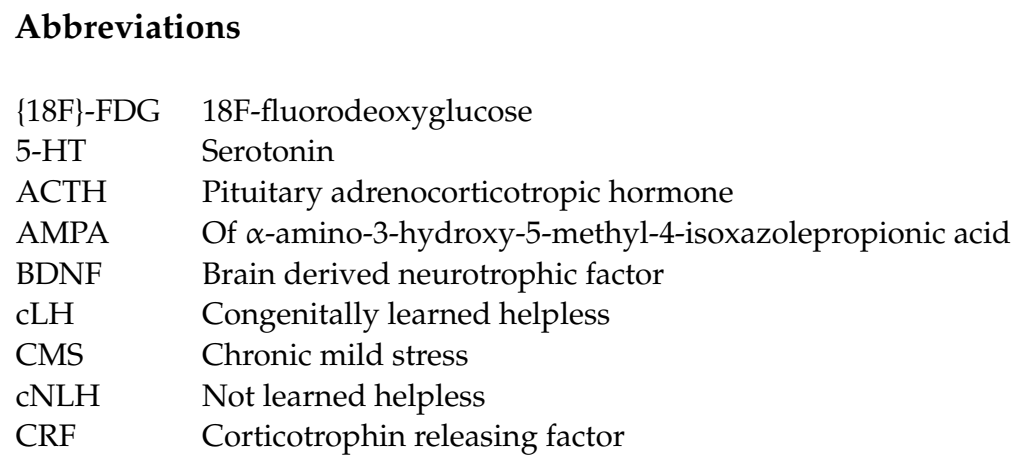




\begin{tabular}{|c|c|}
\hline CRF & Corticotropin-releasing factor \\
\hline CRS & Repeated restraint stress \\
\hline DFP & Diisopropyl fluorophosphate \\
\hline Dom & Dominant mice \\
\hline DSR & The Dominance Submissive Relationship \\
\hline EPM & Elevated Plus Maze \\
\hline ErbB & Family of transmembrane receptor tyrosine kinases (RTKs) \\
\hline $\mathrm{FH} / \mathrm{Wjd}$ & Fawn-Hooded rat \\
\hline FRL & Flinders Resistant Line \\
\hline FSL & Flinders Sensitive Line \\
\hline FST & Forced Swim Test \\
\hline GABA & Gama-aminobutyric acid \\
\hline G-CSF & Granulocyte colony-stimulating factor \\
\hline GluA 1 & Glutamate A1 \\
\hline GR & Glucocorticoid receptor \\
\hline GWAS & Genome-wide association studies \\
\hline HPA & Hypothalamic-pituitary-adrenal \\
\hline HPT & Hypothalamic-pituitary-thyroid \\
\hline ICSS & Intracranial self-stimulation \\
\hline IGF-1 & Insulin-like growth factor 1 \\
\hline IL-6 $\beta$ & Interleukin-6 $\beta$ \\
\hline INF $\gamma$ & Interferon $\gamma$ \\
\hline LH & Learned Helplessness \\
\hline MAPK & Mitogen-activated protein kinase \\
\hline MDD & Major depressive disorder \\
\hline MWM & Morris Water Maze \\
\hline NFkB & Nuclear factor kappa B \\
\hline NPY & Neuropeptide $Y$ \\
\hline NSF & Novelty suppression of feeding \\
\hline OBX & Olfactory bulbectomy \\
\hline PND & Postnatal day \\
\hline RIT & Resident-intruder test \\
\hline SHR & Spontaneously hypertensive rat \\
\hline SI & Social isolation \\
\hline SIS & Social instability stress \\
\hline SPD & Sprague-Dawley rats \\
\hline SPT & Sucrose preference test \\
\hline SSRIs & Selective serotonin reuptake inhibitors \\
\hline Sub & Submissive mice \\
\hline SUDs & Substance use disorders \\
\hline $\mathrm{SwHi}$ & Swim High-Active \\
\hline SwLo & Swim Low-Active \\
\hline SynIIb & Synapsin (Syn) II gene \\
\hline TCA & Tricyclic antidepressants \\
\hline $\mathrm{TNF} \alpha$ & Tumor necrosis factor $\alpha$ \\
\hline TST & Tail Suspension Test \\
\hline VTA & Ventral tegmental area \\
\hline WKY & Wistar-Kyoto rat \\
\hline WT & Wild type mice \\
\hline
\end{tabular}

\section{References}

1. American Psychiatric Association (APA). Diagnostic and Statistical Manual of Mental Disorders, 5th ed.; American Psychiatric Press: Washington, DC, USA, 2013.

2. Vos, T.; Allen, C.; Arora, M.; Barber, R.M.; Bhutta, Z.A.; Brown, A.; Carter, A.; Casey, D.C.; Charlson, F.J.; Chen, A.Z.; et al. Global, regional, and national incidence, prevalence, and years lived with disability for 310 diseases and injuries, 1990-2015: A systematic analysis for the global burden of disease study 2015. Lancet 2016, 388, 1545-1602. [CrossRef]

3. Malhi, G.S.; Mann, J.J. Depression. Lancet 2018, 392, 2299-2312. [CrossRef] 
4. Hasin, D.S.; Sarvet, A.L.; Meyers, J.L.; Saha, T.D.; Ruan, W.J.; Stohl, M.; Grant, B.F. Epidemiology of adult dsm-5 major depressive disorder and its specifiers in the united states. JAMA Psychiatry 2018, 75, 336-346. [CrossRef] [PubMed]

5. Park, L.T.; Zarate, C.A. Depression in the primary care setting. N. Engl. J. Med. 2019, 380, 559-568. [CrossRef] [PubMed]

6. Pu, S.; Setoyama, S.; Noda, T. Association between cognitive deficits and suicidal ideation in patients with major depressive disorder. Sci. Rep. 2017, 7, 1-6. [CrossRef] [PubMed]

7. Hawton, K.; Casañas, C.; Comabella, I.; Haw, C.; Saunders, K. Risk factors for suicide in individuals with depression: A systematic review. J. Disord. 2013, 147, 17-28. [CrossRef] [PubMed]

8. Knipe, D.; Williams, A.J.; Hannam-Swain, S.; Upton, S.; Brown, K.; Bandara, P.; Chang, S.-S.; Kapur, N. Psychiatric morbidity and suicidal behaviour in low- and middle-income countries: A systematic review and meta-analysis. PLoS Med. 2019, 16, e1002905. [CrossRef] [PubMed]

9. Labaka, A.; Goñi-Balentziaga, O.; Lebeña, A.; Pérez-Tejada, J. Biological sex differences in depression: A systematic review. Biol. Res. Nurs. 2018, 20, 383-392. [CrossRef]

10. McKeever, A.; Agius, M.; Mohr, P. A review of the epidemiology of major depressive disorder and of its consequences for society and the individual. Psychiatr. Danub. 2017, 29, 222-231.

11. Sjöberg, L.; Karlsson, B.; Atti, A.R.; Skoog, I.; Fratiglioni, L.; Wang, H.X. Prevalence of depression: Comparisons of different depression definitions in population-based samples of older adults. J. Affect. Disord. 2017, 221, 123-131. [CrossRef]

12. Patten, S.B. An analysis of data from two general health surveys found that increased incidence and duration contributed to elevated prevalence of major depression in persons with chronic medical conditions. J. Clin. Epidemiol. 2005, 58, 184-189. [CrossRef] [PubMed]

13. Banti, S.; Mauri, M.; Oppo, A.; Borri, C.; Rambelli, C.; Ramacciotti, D.; Montagnani, M.S.; Camilleri, V.; Cortopassi, S.; Rucci, P.; et al. From the third month of pregnancy to 1 year postpartum. Prevalence, incidence, recurrence, and new onset of depression. Results from the perinatal depression-research \& screening unit study. Compr. Psychiatry 2011, 52, 343-351. [CrossRef] [PubMed]

14. Pearlstein, T. Depression during Pregnancy. Best Pract. Res. Clin. Obstet. Gynaecol. 2015, 29, 754-764. [CrossRef] [PubMed]

15. Chiriţă, A.L.; Gheorman, V.; Bondari, D.; Rogoveanu, I. Current understanding of the neurobiology of major de-pressive disorder. Rom. J. Morphol. Embryol. 2015, 56, 651-658. [PubMed]

16. Czéh, B.; Fuchs, E.; Wiborg, O.; Simon, M. Animal models of major depression and their clinical implications. Prog. NeuroPsychopharmacol. Biol. Psychiatry 2016, 64, 293-310. [CrossRef]

17. Drevets, W.C.; Price, J.L.; Furey, M.L. Brain structural and functional abnormalities in mood disorders: Implications for neurocircuitry models of depression. Brain Struct. Funct. 2008, 213, 93-118. [CrossRef]

18. Hamon, M.; Blier, P. Monoamine neurocircuitry in depression and strategies for new treatments. Prog. Neuro-Psychopharmacol. Biol. Psychiatry 2013, 45, 54-63. [CrossRef]

19. Nutt, D.J. Relationship of neurotransmitters to the symptoms of major depressive disorder. J. Clin. Psychiatry 2008, 69, 4-7.

20. Lacerda-Pinheiro, S.F.; Junior, R.F.F.P.; De Lima, M.A.P.; Da Silva, C.G.L.; Dos Santos, M.D.S.V.; Júnior, A.G.T.; De Oliveira, P.N.L.; Ribeiro, K.D.B.; Neto, M.L.R.; Bianco, B.A.V. Are there depression and anxiety genetic markers and mutations? A systematic review. J. Affect. Disord. 2014, 168, 387-398. [CrossRef]

21. Corfield, E.C.; Yang, Y.; Martin, N.G.; Nyholt, D.R. A continuum of genetic liability for minor and major depression. Transl. Psychiatry 2017, 7, e1131. [CrossRef]

22. Park, C.; Rosenblat, J.D.; Brietzke, E.; Pan, Z.; Lee, Y.; Cao, B.; Zuckerman, H.; Kalantarova, A.; McIntyre, R.S. Stress, epigenetics and depression: A systematic review. Neurosci. Biobehav. Rev. 2019, 102, 139-152. [CrossRef] [PubMed]

23. MacQueen, G.; Santaguida, P.; Keshavarz, H.; Jaworska, N.; Levine, M.; Beyene, J.; Raina, P. Systematic review of clinical practice guidelines for failed antidepressant treatment response in major depressive disorder, dysthymia, and subthreshold depression in adults. Can. J. Psychiatry 2017, 62, 11-23. [CrossRef] [PubMed]

24. Gorman, J.M. Comorbid depression and anxiety spectrum disorders. Depress. Anxiety 1996, 4, 160-168. [CrossRef]

25. Williamson, D.E.; Forbes, E.E.; Dahl, R.E.; Ryan, N.D. A Genetic Epidemiologic Perspective on Comorbidity of Depression and Anxiety. Child Adolesc. Psychiatr. Clin. N. Am. 2005, 14, 707-726. [CrossRef] [PubMed]

26. Czéh, B.; Simon, M. Benefits of animal models to understand the pathophysiology of depressive disorders. Prog. NeuroPsychopharmacol. Biol. Psychiatry 2020, 106, 110049. [CrossRef] [PubMed]

27. Nestler, E.J.; Hyman, S.E. Animal models of neuropsychiatric disorders. Nat. Neurosci. 2010, 13, 1161-1169. [CrossRef] [PubMed]

28. Willner, P. Animal models of depression: An overview. Pharmacol. Ther. 1990, 45, 425-455. [CrossRef]

29. Belzung, C.; Lemoine, M. Criteria of validity for animal models of psychiatric disorders: Focus on anxiety disorders and depression. Biol. Mood Anxiety Disord. 2011, 1, 9. [CrossRef]

30. Gururajan, A.; Reif, A.; Cryan, J.F.; Slattery, D.A. The future of rodent models in depression research. Nat. Rev. Neurosci. 2019, 20, 686-701. [CrossRef]

31. Yankelevitch-Yahav, R.; Franko, M.; Huly, A.; Doron, R. The Forced Swim Test as a Model of Depressive-like Behavior. J. Vis. Exp. 2015, 97, e52587. [CrossRef]

32. Cryan, J.F.; Mombereau, C.; Vassout, A. The tail suspension test as a model for assessing antidepressant activity: Review of pharmacological and genetic studies in mice. Neurosci. Biobehav. Rev. 2005, 29, 571-625. [CrossRef] [PubMed]

33. Carola, V.; D'Olimpio, F.; Brunamonti, E.; Mangia, F.; Renzi, P. Evaluation of the elevated plus-maze and open-field tests for the assessment of anxiety-related behaviour in inbred mice. Behav. Brain Res. 2002, 134, 49-57. [CrossRef] 
34. Papp, M.; Willner, P.; Muscat, R. An animal model of anhedonia: Attenuation of sucrose consumption and place preference conditioning by chronic unpredictable mild stress. Psychopharmacology 1991, 104, 255-259. [CrossRef] [PubMed]

35. Isingrini, E.; Camus, V.; Le Guisquet, A.-M.; Pingaud, M.; Devers, S.; Belzung, C. Association between repeated unpredictable chronic mild stress (ucms) procedures with a high fat diet: A model of fluoxetine resistance in mice. PLoS ONE 2010, 5, e10404. [CrossRef]

36. Crawley, J.N.; Chen, T.; Puri, A.; Washburn, R.; Sullivan, T.L.; Hill, J.M.; Young, N.B.; Nadler, J.J.; Moy, S.S.; Young, L.J.; et al. Social approach behaviors in oxytocin knockout mice: Comparison of two independent lines tested in different laboratory environments. Neuropeptides 2007, 41, 145-163. [CrossRef] [PubMed]

37. Cathomas, F.; Hartmann, M.N.; Seifritz, E.; Pryce, C.R.; Ekaiser, S. The translational study of apathy-An ecological approach. Front. Behav. Neurosci. 2015, 9, 241. [CrossRef]

38. Castagné, V.; Moser, P.; Porsolt, R.D. Behavioral Assessment of Antidepressant Activity in Rodents; CRC Press/Taylor \& Francis: Boca Raton, FL, USA, 2009. Available online: https://www.ncbi.nlm.nih.gov/books/NBK5222/ (accessed on 28 December 2020).

39. Levy, R.; Dubois, B. Apathy and the Functional Anatomy of the Prefrontal Cortex-Basal Ganglia Circuits. Cereb. Cortex 2006, 16, 916-928. [CrossRef]

40. Planchez, B.; Surget, A.; Belzung, C. Animal models of major depression: Drawbacks and challenges. J. Neural Transm. 2019, 126, 1383-1408. [CrossRef]

41. Willner, P. Chronic Mild Stress (CMS) Revisited: Consistency and Behavioural-Neurobiological Concordance in the Effects of CMS. Neuropsychobiology 2005, 52, 90-110. [CrossRef]

42. Bailey, K.R.; Crawley, J.N. Anxiety-Related Behaviors in Mice, 2nd ed.; Chapter 5; CRC Press/Taylor \& Francis: Boca Raton, FL, USA, 2009. Available online: https:/ / www.ncbi.nlm.nih.gov/books/NBK5221/ (accessed on 28 December 2020).

43. Lezak, K.R.; Missig, G.; Carlezon, W.A., Jr. Behavioral methods to study anxiety in rodents. Dialog. Clin. Neurosci. 2017, 19, 181-191.

44. Shepherd, J.K.; Grewal, S.S.; Fletcher, A.; Bill, D.J.; Dourish, C.T. Behavioural and pharmacological characterisation of the elevated "zero-maze" as an animal model of anxiety. Psychopharmacology 1994, 116, 56-64. [CrossRef] [PubMed]

45. Seibenhener, M.L.; Wooten, M.C. Use of the open field maze to measure locomotor and anxiety-like behavior in mice. J. Vis. Exp. 2015, 96, e52434. [CrossRef] [PubMed]

46. Blasco-Serra, A.; González-Soler, E.M.; Cervera-Ferri, A.; Teruel-Martí, V.; Valverde-Navarro, A.A. A standardization of the Novelty-Suppressed Feeding Test protocol in rats. Neurosci. Lett. 2017, 658, 73-78. [CrossRef] [PubMed]

47. Deacon, R.M. Hyponeophagia: A Measure of Anxiety in the Mouse. J. Vis. Exp. 2011, 51, e2613. [CrossRef] [PubMed]

48. Moy, S.S.; Nadler, J.J.; Young, N.B.; Perez, A.; Holloway, L.P.; Barbaro, R.P.; Barbaro, J.R.; Wilson, L.M.; Threadgill, D.W.; Lauder, J.M. Mouse behavioral tasks relevant to autism: Phenotypes of 10 inbred strains. Behav. Brain Res. 2007, 176, 4-20. [CrossRef] [PubMed]

49. Cryan, J.F.; Hoyer, D.; Markou, A. Withdrawal from chronic amphetamine induces Depressive-Like behavioral effects in rodents. Biol. Psychiatry 2003, 54, 49-58. [CrossRef]

50. Culpepper, L.; Lam, R.W.; McIntyre, R.S. Cognitive Impairment in Patients with Depression: Awareness, Assessment, and Management. J. Clin. Psychiatry 2017, 78, 1383-1394. [CrossRef]

51. Vorhees, C.V.; Williams, M.T. Morris water maze: Procedures for assessing spatial and related forms of learning and memory. Nat. Protoc. 2006, 1, 848-858. [CrossRef]

52. Kraeuter, A.-K.; Guest, P.C.; Sarnyai, Z. The y-maze for assessment of spatial working and reference memory in mice. Comput. Biol. 2019, 1916, 105-111. [CrossRef]

53. Sarnyai, Z.; Sibille, E.L.; Pavlides, C.; Fenster, R.J.; McEwen, B.S.; Tóth, M. Impaired hippocampal-dependent learning and functional abnormalities in the hippocampus in mice lacking serotonin1A receptors. Proc. Natl. Acad. Sci. USA 2000, 97, 14731-14736. [CrossRef]

54. Komori, T.; Makinodan, M.; Kishimoto, T. Social status and modern-type depression: A review. Brain Behav. 2019, 9, e01464. [CrossRef] [PubMed]

55. Crawley, J.N. Designing mouse behavioral tasks relevant to autistic-like behaviors. Ment. Retard. Dev. Disabil. Res. Rev. 2004, 10, 248-258. [CrossRef] [PubMed]

56. Berger, S.; Gureczny, S.; Reisinger, S.N.; Horvath, O.; Pollak, D.D. Effect of chronic corticosterone treatment on depression-like behavior and sociability in female and male c57bl/6n mice. Cells 2019, 8, 1018. [CrossRef] [PubMed]

57. Jaehne, E.J.; Klaric, T.; Koblar, S.A.; Baune, B.; Lewis, M.D. Effects of Npas4 deficiency on anxiety, depression-like, cognition and sociability behaviour. Behav. Brain Res. 2015, 281, 276-282. [CrossRef] [PubMed]

58. Zheng, Y.; Fan, W.; Zhang, X.; Dong, E. Gestational stress induces depressive-like and anxiety-like phenotypes through epigenetic regulation of BDNF expression in offspring hippocampus. Epigenetics 2016, 11, 150-162. [CrossRef] [PubMed]

59. Frye, C.A.; Wawrzycki, J. Effect of prenatal stress and gonadal hormone condition on depressive behaviors of female and male rats. Horm. Behav. 2003, 44, 319-326. [CrossRef]

60. Morley-Fletcher, S.; Darnaudery, M.; Koehl, M.; Casolini, P.; Van Reeth, O.; Maccari, S. Prenatal stress in rats predicts immobility behavior in the forced swim test. Brain Res. 2003, 989, 246-251. [CrossRef]

61. Jia, N.; Li, Q.; Sun, H.; Song, Q.; Tang, G.; Sun, Q.; Wang, W.; Chen, R.; Li, H.; Zhu, Z. Alterations of Group I mGluRs and BDNF Associated with Behavioral Abnormity in Prenatally Stressed Offspring Rats. Neurochem. Res. 2015, 40, 1074-1082. [CrossRef] 
62. Akatsu, S.; Ishikawa, C.; Takemura, K.; Ohtani, A.; Shiga, T. Effects of prenatal stress and neonatal handling on anxiety, spatial learning and serotonergic system of male offspring mice. Neurosci. Res. 2015, 101, 15-23. [CrossRef]

63. Henry, C.; Kabbaj, M.; Simon, H.; Moal, M.; Maccari, S. Prenatal Stress Increases the Hypothalamo-Pituitary-Adrenal Axis Response in Young and Adult Rats. J. Neuroendocr. 1994, 6, 341-345. [CrossRef]

64. Rice, D.; Barone, S. Critical periods of vulnerability for the developing nervous system: Evidence from humans and animal models. Environ. Health Perspect. 2000, 108, 511-533. [CrossRef] [PubMed]

65. Semple, B.D.; Blomgren, K.; Gimlin, K.; Ferriero, D.M.; Noble-Haeusslein, L.J. Brain development in rodents and humans: Identifying benchmarks of maturation and vulnerability to injury across species. Prog. Neurobiol. 2013, 106-107, 1-16. [CrossRef] [PubMed]

66. Bayer, S.A.; Altman, J.; Russo, R.J.; Zhang, X. Timetables of neurogenesis in the human brain based on experi-mentally determined patterns in the rat. Neurotoxicology 1993, 14, 83-144. [PubMed]

67. Romeo, R.D.; Mueller, A.; Sisti, H.M.; Ogawa, S.; McEwen, B.S.; Brake, W.G. Anxiety and fear behaviors in adult male and female C57BL/ 6 mice are modulated by maternal separation. Horm. Behav. 2003, 43, 561-567. [CrossRef]

68. Goodwill, H.L.; Manzano-Nieves, G.; Gallo, M.; Lee, H.-I.; Oyerinde, E.; Serre, T.; Bath, K.G. Early life stress leads to sex differences in development of depressive-like outcomes in a mouse model. Neuropsychopharmacology 2019, 44, 711-720. [CrossRef]

69. Rice, C.J.; Sandman, C.A.; Lenjavi, M.R.; Baram, T.Z. A Novel Mouse Model for Acute and Long-Lasting Consequences of Early Life Stress. Endocrinology 2008, 149, 4892-4900. [CrossRef]

70. Marais, L.; Van Rensburg, S.J.; Van Zyl, J.M.; Stein, D.J.; Daniels, W.M. Maternal separation of rat pups increases the risk of developing depressive-like behavior after subsequent chronic stress by altering corticosterone and neurotrophin levels in the hippocampus. Neurosci. Res. 2008, 61, 106-112. [CrossRef]

71. Van Bodegom, M.; Homberg, J.R.; Henckens, M.J.A.G. Modulation of the Hypothalamic-Pituitary-Adrenal Axis by Early Life Stress Exposure. Front. Cell. Neurosci. 2017, 11, 87. [CrossRef]

72. Tractenberg, S.G.; Levandowski, M.L.; De Azeredo, L.A.; Orso, R.; Roithmann, L.G.; Hoffmann, E.S.; Brenhouse, H.; GrassiOliveira, R. An overview of maternal separation effects on behavioural outcomes in mice: Evidence from a four-stage methodological systematic review. Neurosci. Biobehav. Rev. 2016, 68, 489-503. [CrossRef]

73. Millstein, R.A.; Holmes, A. Effects of repeated maternal separation on anxiety- and depression-related phenotypes in different mouse strains. Neurosci. Biobehav. Rev. 2007, 31, 3-17. [CrossRef]

74. Bhansali, P.; Dunning, J.; Singer, S.E.; David, L.; Schmauss, C. Early Life Stress Alters Adult Serotonin 2C Receptor Pre-mRNA Editing and Expression of the $\alpha$ Subunit of the Heterotrimeric G-Protein Gq. J. Neurosci. 2007, 27, 1467-1473. [CrossRef] [PubMed]

75. Fone, K.C.; Porkess, M.V. Behavioural and neurochemical effects of post-weaning social isolation in rodents-Relevance to developmental neuropsychiatric disorders. Neurosci. Biobehav. Rev. 2008, 32, 1087-1102. [CrossRef] [PubMed]

76. Amiri, S.; Haj-Mirzaian, A.; Rahimi-Balaei, M.; Razmi, A.; Kordjazy, N.; Shirzadian, A.; Mehr, S.E.; Sianati, H.; Rashidian, A. Co-occurrence of anxiety and depressive-like behaviors following adolescent social isolation in male mice; possible role of nitrergic system. Physiol. Behav. 2015, 145, 38-44. [CrossRef] [PubMed]

77. Ferdman, N.; Murmu, R.P.; Bock, J.; Braun, K.; Leshem, M. Weaning age, social isolation, and gender, interact to determine adult explorative and social behavior, and dendritic and spine morphology in prefrontal cortex of rats. Behav. Brain Res. 2007, 180, 174-182. [CrossRef]

78. Du Preez, A.; Law, T.; Onorato, D.; Lim, Y.M.; Eiben, P.; Musaelyan, K.; Egeland, M.; Hye, A.; Zunszain, P.A.; Thuret, S.; et al. The type of stress matters: Repeated injection and permanent social isolation stress in male mice have a differential effect on anxietyand depressive-like behaviours, and associated biological alterations. Transl. Psychiatry 2020, 10, 1-17. [CrossRef]

79. Weiss, I.C.; Pryce, C.R.; Jongen-Rêlo, A.L.; Nanz-Bahr, N.I.; Feldon, J. Effect of social isolation on stress-related behavioural and neuroendocrine state in the rat. Behav. Brain Res. 2004, 152, 279-295. [CrossRef]

80. Chappell, A.M.; Carter, E.; McCool, B.A.; Weiner, J.L. Adolescent rearing conditions influence the relationship between initial anxiety-like behavior and ethanol drinking in male long evans rats. Alcohol. Clin. Exp. Res. 2013, 37, E394-E403. [CrossRef]

81. Skelly, M.J.; Chappell, A.E.; Carter, E.; Weiner, J.L. Adolescent social isolation increases anxiety-like behavior and ethanol intake and impairs fear extinction in adulthood: Possible role of disrupted noradrenergic signaling. Neuropharmacology 2015, 97, 149-159. [CrossRef]

82. Rivera-Irizarry, J.K.; Skelly, M.J.; Pleil, K.E. Social Isolation Stress in Adolescence, but not Adulthood, Produces Hypersocial Behavior in Adult Male and Female C57BL/6J Mice. Front. Behav. Neurosci. 2020, 14, 129. [CrossRef]

83. Walker, D.M.; Cunningham, A.M.; Gregory, J.K.; Nestler, E.J. Long-Term Behavioral Effects of Post-weaning Social Isolation in Males and Females. Front. Behav. Neurosci. 2019, 13, 66. [CrossRef]

84. Lukkes, J.L.; Watt, M.J.; Lowry, C.A.; Forster, G.L. Consequences of post-weaning social isolation on anxiety behavior and related neural circuits in rodents. Front. Behav. Neurosci. 2009, 3, 18. [CrossRef] [PubMed]

85. Burke, A.R.; McCormick, C.M.; Pellis, S.M.; Lukkes, J.L. Impact of adolescent social experiences on behavior and neural circuits implicated in mental illnesses. Neurosci. Biobehav. Rev. 2017, 76, 280-300. [CrossRef] [PubMed]

86. McCormick, C.M.; Green, M. From the stressed adolescent to the anxious and depressed adult: Investigations in rodent models. Neuroscience 2013, 249, 242-257. [CrossRef] [PubMed]

87. Famitafreshi, H.; Morteza, K. Social Isolation Rearing Induces Neuropsychiatric Diseases: Updated Overview. Mol. Neuropsychiatry 2019, 4, 190-195. [CrossRef] 
88. Mumtaz, F.; Imran-Khan, M.; Zubair, M.; Rashidian, A. Neurobiology and consequences of social isolation stress in animal model-A comprehensive review. Biomed. Pharmacother. 2018, 105, 1205-1222. [CrossRef]

89. Berry, A.; Bellisario, V.; Capoccia, S.; Tirassa, P.; Calza, A.; Alleva, E.; Cirulli, F. Social deprivation stress is a triggering factor for the emergence of anxiety- and depression-like behaviours and leads to reduced brain BDNF levels in C57BL/6J mice. Psychoneuroendocrinology 2012, 37, 762-772. [CrossRef]

90. Ieraci, A.; Mallei, A.; Popoli, M. Social Isolation Stress Induces Anxious-Depressive-Like Behavior and Alterations of Neuroplasticity-Related Genes in Adult Male Mice. Neural Plast. 2016, 2016, 1-13. [CrossRef]

91. Pibiri, F.; Nelson, M.; Guidotti, A.; Costa, E.; Pinna, G. Decreased corticolimbic allopregnanolone expression during social isolation enhances contextual fear: A model relevant for posttraumatic stress disorder. Proc. Natl. Acad. Sci. USA 2008, 105, 5567-5572. [CrossRef]

92. Djordjevic, A.; Adzic, M.; Djordjevic, J.; Radojcic, M.B. Stress Type Dependence of Expression and Cytoplasmic-Nuclear Partitioning of Glucocorticoid Receptor, Hsp90 and Hsp70 in Wistar Rat Brain. Neuropsychobiology 2009, 59, 213-221. [CrossRef]

93. Martin, A.L.; Brown, R.E. The lonely mouse: Verification of a separation-induced model of depression in female mice. Behav. Brain Res. 2010, 207, 196-207. [CrossRef]

94. Bartolomucci, A.; Palanza, P.; Sacerdote, P.; Ceresini, G.; Chirieleison, A.; Panerai, A.E.; Parmigiani, S. Individual housing induces altered immuno-endocrine responses to psychological stress in male mice. Psychoneuroendocrinology 2003, 28, 540-558. [CrossRef]

95. Voikar, V.; Polus, A.; Vasar, E.; Rauvala, H. Long-term individual housing in C57BL/6J and DBA/2 mice: Assessment of behavioral consequences. Genes Brain Behav. 2004, 4, 240-252. [CrossRef] [PubMed]

96. Arndt, S.S.; Laarakker, M.C.; Van Lith, H.A.; Van Der Staay, F.J.; Gieling, E.; Salomons, A.R.; Klooster, J.V.; Ohl, F. Individual housing of mice-Impact on behaviour and stress responses. Physiol. Behav. 2009, 97, 385-393. [CrossRef] [PubMed]

97. Farbstein, D.; Hollander, N.; Peled, O.; Apter, A.; Fennig, S.; Haberman, Y.; Gitman, H.; Yaniv, I.; Shkalim, V.; Pick, C.G.; et al. Social isolation in mice: Behavior, immunity, and tumor growth. Stress 2020, 1-10. [CrossRef] [PubMed]

98. Vollmayr, B.; Bachteler, D.; Vengeliene, V.; Gass, P.; Spanagel, R.; Henn, F. Rats with congenital learned helplessness respond less to sucrose but show no deficits in activity or learning. Behav. Brain Res. 2004, 150, 217-221. [CrossRef]

99. Palma, B.D.; Suchecki, D.; Tufik, S. Differential effects of acute cold and footshock on the sleep of rats. Brain Res. 2000, 861, 97-104. [CrossRef]

100. Henn, F.A.; Vollmayr, B. Stress models of depression: Forming genetically vulnerable strains. Neurosci. Biobehav. Rev. 2005, 29, 799-804. [CrossRef]

101. Maudhuit, C.; Prévot, E.; Dangoumau, L.; Martin, P.; Hamon, M.; Adrien, J. Antidepressant treatment in helpless rats: Effect on the electrophysiological activity of raphe dorsalis serotonergic neurons. Psychopharmacology 1997, 130, 269-275. [CrossRef]

102. Hajszan, T.; Dow, A.; Warner-Schmidt, J.L.; Szigeti-Buck, K.; Sallam, N.L.; Parducz, A.; Leranth, C.; Duman, R.S. Remodeling of Hippocampal Spine Synapses in the Rat Learned Helplessness Model of Depression. Biol. Psychiatry 2009, 65, 392-400. [CrossRef]

103. Malberg, J.E.; Duman, R.S. Cell Proliferation in Adult Hippocampus is Decreased by Inescapable Stress: Reversal by Fluoxetine Treatment. Neuropsychopharmacology 2003, 28, 1562-1571. [CrossRef]

104. Willner, P.; Towell, A.; Sampson, D.; Sophokleous, S.; Muscat, R. Reduction of sucrose preference by chronic unpredictable mild stress, and its restoration by a tricyclic antidepressant. Psychopharmacology 1987, 93, 358-364. [CrossRef] [PubMed]

105. Willner, P. The chronic mild stress (CMS) model of depression: History, evaluation and usage. Neurobiol. Stress 2017, 6, 78-93. [CrossRef] [PubMed]

106. Pothion, S.; Bizot, J.-C.; Trovero, F.; Belzung, C. Strain differences in sucrose preference and in the consequences of unpredictable chronic mild stress. Behav. Brain Res. 2004, 155, 135-146. [CrossRef] [PubMed]

107. Sequeira-Cordero, A.; Salas-Bastos, A.; Fornaguera, J.; Brenes, J.C. Behavioural characterisation of chronic unpredictable stress based on ethologically relevant paradigms in rats. Sci. Rep. 2019, 9, 17403-17421. [CrossRef] [PubMed]

108. Rudyk, C.; Dwyer, Z.; McNeill, J.; Salmaso, N.; Farmer, K.; Prowse, N.; Hayley, S. Chronic unpredictable stress influenced the behavioral but not the neurodegenerative impact of paraquat. Neurobiol. Stress 2019, 11, 100179. [CrossRef] [PubMed]

109. Hu, C.; Luo, Y.; Wang, H.; Kuang, S.; Liang, G.; Yang, Y.; Mai, S.; Yang, J. Re-evaluation of the interrelationships among the behavioral tests in rats exposed to chronic unpredictable mild stress. PLoS ONE 2017, 12, e0185129. [CrossRef] [PubMed]

110. Willner, P. Validity, reliability and utility of the chronic mild stress model of depression: A 10-year review and evaluation. Psychopharmacology 1997, 134, 319-329. [CrossRef]

111. Hill, M.N.; Hellemans, K.G.; Verma, P.; Gorzalka, B.B.; Weinberg, J. Neurobiology of chronic mild stress: Parallels to major depression. Neurosci. Biobehav. Rev. 2012, 36, 2085-2117. [CrossRef]

112. Christiansen, S.; Olesen, M.; Wörtwein, G.; Woldbye, D.P.D. Fluoxetine reverts chronic restraint stress-induced depression-like behaviour and increases neuropeptide $Y$ and galanin expression in mice. Behav. Brain Res. 2011, 216, 585-591. [CrossRef]

113. Grizzell, J.A.; Iarkov, A.; Holmes, R.; Mori, T.; Echeverria, V. Cotinine reduces depressive-like behavior, working memory deficits, and synaptic loss associated with chronic stress in mice. Behav. Brain Res. 2014, 268, 55-65. [CrossRef]

114. Kim, K.-S.; Han, P.-L. Optimization of chronic stress paradigms using anxiety- and depression-like behavioral parameters. J. Neurosci. Res. 2006, 83, 497-507. [CrossRef] [PubMed]

115. Park, M.-J.; Seo, B.A.; Lee, B.; Shin, H.-S.; Kang, M.-G. Stress-induced changes in social dominance are scaled by AMPA-type glutamate receptor phosphorylation in the medial prefrontal cortex. Sci. Rep. 2018, 8, 15008. [CrossRef] [PubMed] 
116. Huang, P.; Li, C.; Fu, T.; Zhao, D.; Yi, Z.; Lu, Q.; Guo, L.; Xu, X. Flupirtine attenuates chronic restraint stress-induced cognitive deficits and hippocampal apoptosis in male mice. Behav. Brain Res. 2015, 288, 1-10. [CrossRef] [PubMed]

117. Xu, P.; Wang, K.; Lu, C.; Dong, L.; Chen, Y.; Wang, Q.; Shi, Z.; Yang, Y.; Chen, S.; Liu, X. Effects of the chronic restraint stress induced depression on reward-related learning in rats. Behav. Brain Res. 2017, 321, 185-192. [CrossRef] [PubMed]

118. Woo, H.; Hong, C.J.; Jung, S.; Choe, S.; Yu, S.-W. Chronic restraint stress induces hippocampal memory deficits by impairing insulin signaling. Mol. Brain 2018, 11, 37. [CrossRef]

119. Kessler, R.C. The effects of stressful life events on depression. Annu. Rev. Psychol. 1997, 48, 191-214. [CrossRef]

120. Sloman, L. Evolved mechanisms in depression: The role and interaction of attachment and social rank in depression. J. Affect. Disord. 2003, 74, 107-121. [CrossRef]

121. Rygula, R.; Abumaria, N.; Flügge, G.; Fuchs, E.; Rüther, E.; Havemann-Reinecke, U. Anhedonia and motivational deficits in rats: Impact of chronic social stress. Behav. Brain Res. 2005, 162, 127-134. [CrossRef]

122. Krishnan, V.; Han, M.-H.; Graham, D.L.; Berton, O.; Renthal, W.; Russo, S.J.; LaPlant, Q.; Graham, A.; Lutter, M.; Lagace, D.C.; et al. Molecular Adaptations Underlying Susceptibility and Resistance to Social Defeat in Brain Reward Regions. Cell 2007, 131, 391-404. [CrossRef]

123. Berton, O.; McClung, C.A.; Dileone, R.J.; Krishnan, V.; Renthal, W.; Russo, S.J.; Graham, D.; Tsankova, N.M.; Bolanos, C.A.; Rios, M.; et al. Essential Role of BDNF in the Mesolimbic Dopamine Pathway in Social Defeat Stress. Science 2006, 311, 864-868. [CrossRef]

124. Tsankova, N.M.; Berton, O.; Renthal, W.; Kumar, A.; Neve, R.L.; Nestler, E.J. Sustained hippocampal chromatin regulation in a mouse model of depression and antidepressant action. Nat. Neurosci. 2006, 9, 519-525. [CrossRef] [PubMed]

125. Avgustinovich, D.F.; Kovalenko, I.L.; Kudryavtseva, N.N. A Model of Anxious Depression: Persistence of Behavioral Pathology. Neurosci. Behav. Physiol. 2005, 35, 917-924. [CrossRef] [PubMed]

126. Haller, J.; Fuchs, E.; Halasz, J.; Makara, G.B. Defeat is a major stressor in males while social instability is stressful mainly in females: Towards the development of a social stress model in female rats. Brain Res. Bull. 1999, 50, 33-39. [CrossRef]

127. Goñi-Balentziaga, O.; Pérez-Tejada, J.; Renteria-Dominguez, A.; Lebeña, A.; Labaka, A. Social instability in female rodents as a model of stress related disorders: A systematic review. Physiol. Behav. 2018, 196, 190-199. [CrossRef] [PubMed]

128. Jarcho, M.; Massner, K.; Eggert, A.; Wichelt, E. Behavioral and physiological response to onset and termination of social instability in female mice. Horm. Behav. 2016, 78, 135-140. [CrossRef]

129. Labaka, A.; Gómez-Lázaro, E.; Vegas, O.; Pérez-Tejada, J.; Arregi, A.; Garmendia, L. Reduced hippocampal IL-10 expression, altered monoaminergic activity and anxiety and depressive-like behavior in female mice subjected to chronic social instability stress. Behav. Brain Res. 2017, 335, 8-18. [CrossRef]

130. Morales-Medina, J.C.; Iannitti, T.; Freeman, A.R.; Caldwell, H.K. The olfactory bulbectomized rat as a model of depression: The hippocampal pathway. Behav. Brain Res. 2017, 317, 562-575. [CrossRef]

131. Hozumi, S.; Nakagawasai, O.; Tan-No, K.; Niijima, F.; Yamadera, F.; Murata, A.; Arai, Y.; Yasuhara, H.; Tadano, T. Characteristics of changes in cholinergic function and impairment of learning and memory-related behavior induced by olfactory bulbectomy. Behav. Brain Res. 2003, 138, 9-15. [CrossRef]

132. Takahashi, K.; Nakagawasai, O.; Nemoto, W.; Odaira, T.; Arai, Y.; Hisamitsu, T.; Tan-No, K. Time-dependent role of prefrontal cortex and hippocampus on cognitive improvement by aripiprazole in olfactory bulbectomized mice. Eur. Neuropsychopharmacol. 2017, 27, 1000-1010. [CrossRef]

133. Van Riezen, H.; Leonard, B. Effects of psychotropic drugs on the behavior and neurochemistry of olfactory bulbectomized rats. Pharmacol. Ther. 1990, 47, 21-34. [CrossRef]

134. Takahashi, K.; Nakagawasai, O.; Nemoto, W.; Odaira, T.; Sakuma, W.; Tan-No, K. Antidepressant-like effect of aripiprazole via 5-HT1A, D1, and D2 receptors in the prefrontal cortex of olfactory bulbectomized mice. J. Pharmacol. Sci. 2018, 137, 241-247. [CrossRef] [PubMed]

135. Kelly, J.; Wrynn, A.; Leonard, B. The olfactory bulbectomized rat as a model of depression: An update. Pharmacol. Ther. 1997, 74, 299-316. [CrossRef]

136. Zhou, Y.; Tao, X.; Wang, Z.; Feng, L.; Wang, L.; Liu, X.; Pan, R.-L.; Liao, Y.; Chang, Q. Hippocampus Metabolic Disturbance and Autophagy Deficiency in Olfactory Bulbectomized Rats and the Modulatory Effect of Fluoxetine. Int. J. Mol. Sci. 2019, $20,4282$. [CrossRef] [PubMed]

137. Kalshetti, P.B.; Alluri, R.; Thakurdesai, P.A. Antidepressant effects of standardized extract of Commiphora mukul Engl. in olfactory bulbectomized rats. Braz. Arch. Biol. Technol. 2015, 58, 41-48. [CrossRef]

138. Pudell, C.; Vicente, B.A.; Delattre, A.M.; Carabelli, B.; Mori, M.A.; Suchecki, D.; Machado, R.B.; Zanata, S.M.; Visentainer, J.V.; Santos, O.D.O.; et al. Fish oil improves anxiety-like, depressive-like and cognitive behaviors in olfactory bulbectomised rats. Eur. J. Neurosci. 2012, 39, 266-274. [CrossRef]

139. Morales-Medina, J.C.; Dumont, Y.; Benoit, C.-E.; Bastianetto, S.; Flores, G.; Fournier, A.; Quirion, R. Role of neuropeptide Y Y1 and $\mathrm{Y} 2$ receptors on behavioral despair in a rat model of depression with co-morbid anxiety. Neuropharmacology 2012, 62, 200-208. [CrossRef]

140. Rinwa, P.; Kumar, P.; Garg, S. Suppression of Neuroinflammatory and Apoptotic Signaling Cascade by Curcumin Alone and in Combination with Piperine in Rat Model of Olfactory Bulbectomy Induced Depression. PLoS ONE 2013, 8, e61052. [CrossRef] 
141. Vanrijzingen, I.; Gispen, W.; Spruijt, B. Olfactory bulbectomy temporarily impairs Morris maze performance: An ACTH(4?9) analog accellerates return of function. Physiol. Behav. 1995, 58, 147-152. [CrossRef]

142. Olton, D.S.; Collison, C.; Werz, M.A. Spatial memory and radial arm maze performance of rats. Learn. Motiv. 1977, 8, 289-314. [CrossRef]

143. Morales-Medina, J.; Juarez, I.; Venancio-García, E.; Cabrera, S.; Menard, C.; Yu, W.; Flores, G.; Mechawar, N.; Quirion, R. Impaired structural hippocampal plasticity is associated with emotional and memory deficits in the olfactory bulbectomized rat. Neuroscience 2013, 236, 233-243. [CrossRef]

144. Song, C.; Leonard, B.E. The olfactory bulbectomised rat as a model of depression. Neurosci. Biobehav. Rev. 2005, $29,627-647$. [CrossRef] [PubMed]

145. Antkiewicz-Michaluk, L.; Wąsik, A.; Możdżeń, E.; Romańska, I.; Michaluk, J. Antidepressant-like Effect of Tetrahydroisoquinoline Amines in the Animal Model of Depressive Disorder Induced by Repeated Administration of a Low Dose of Reserpine: Behavioral and Neurochemical Studies in the Rat. Neurotox. Res. 2014, 26, 85-98. [CrossRef] [PubMed]

146. Rojas-Corrales, M.O.; Berrocoso, E.; Gibert-Rahola, J.; Micó, J.A. Antidepressant-like effect of tramadol and its enantiomers in reserpinized mice: Comparative study with desipramine, fluvoxamine, venlafaxine and opiates. J. Psychopharmacol. 2004, 18, 404-411. [CrossRef] [PubMed]

147. Ruiz, P.; Calliari, A.; Pautassi, R.M. Reserpine-induced depression is associated in female, but not in male, adolescent rats with heightened, fluoxetine-sensitive, ethanol consumption. Behav. Brain Res. 2018, 348, 160-170. [CrossRef] [PubMed]

148. Skalisz, L. Evaluation of the face validity of reserpine administration as an animal model of depression-Parkinson's disease association. Prog. Neuro-Psychopharmacol. Biol. Psychiatry 2002, 26, 879-883. [CrossRef]

149. Socała, K.; Nieoczym, D.; Pieróg, M.; Szuster-Ciesielska, A.; Wyska, E.; Wlaź, P. Antidepressant-like activity of sildenafil following acute and subchronic treatment in the forced swim test in mice: Effects of restraint stress and monoamine depletion. Metab. Brain Dis. 2016, 31, 1095-1104. [CrossRef]

150. Wang, G.-L.; He, Z.-M.; Zhu, H.-Y.; Gao, Y.; Zhao, Y.; Yang, H.; Zhang, L. Involvement of serotonergic, noradrenergic and dopaminergic systems in the antidepressant-like effect of ginsenoside Rb1, a major active ingredient of Panax ginseng C.A. Meyer. J. Ethnopharmacol. 2017, 204, 118-124. [CrossRef]

151. Yu, H.; Lv, D.; Shen, M.; Zhang, Y.; Zhou, D.; Chen, Z.; Wang, C. BDNF mediates the protective effects of scopolamine in reserpine-induced depression-like behaviors via up-regulation of 5-HTT and TPH1. Psychiatry Res. 2019, 271, 328-334. [CrossRef]

152. Khurana, K.; Bansal, N. Lacidipine attenuates reserpine-induced depression-like behavior and oxido-nitrosative stress in mice. Naunyn-Schmiedeberg's Arch. Pharmacol. 2019, 392, 1265-1275. [CrossRef]

153. Wei, G.; Su, H.; He, F.; Lu, W.; Lu, G.; Huang, Z.; Tan, X.; Lin, X.; Zeng, X.; Wei, B.; et al. Antidepressant-like effect of active fraction of polyrhachisvicina roger in a rat depression model. J. Tradit. Chin. Med. 2018, 38, 12-21.

154. Park, B.-K.; Kim, Y.R.; Kim, Y.H.; Yang, C.; Seo, C.-S.; Jung, I.C.; Jang, I.-S.; Kim, S.-H.; Lee, M.Y. Antidepressant-Like Effects of Gyejibokryeong-hwan in a Mouse Model of Reserpine-Induced Depression. BioMed Res. Int. 2018, 2018, 1-12. [CrossRef] [PubMed]

155. Hao, Y.; Ge, H.; Sun, M.; Gao, Y. Selecting an Appropriate Animal Model of Depression. Int. J. Mol. Sci. 2019, 20, 4827. [CrossRef] [PubMed]

156. Mahesh, R.; Jindal, A.; Gautam, B.; Bhatt, S.; Pandey, D. Evaluation of anti-depressant-like activity of linezolid, an oxazolidinone class derivative-An investigation using behavioral tests battery of depression. Biochem. Biophys. Res. Commun. 2011, 409, 723-726. [CrossRef] [PubMed]

157. Leão, A.H.; Sarmento-Silva, A.J.; Santos, J.R.; Ribeiro, A.M.; Silva, R.H. Molecular, Neurochemical, and Behavioral Hallmarks of Reserpine as a Model for Parkinson's Disease: New Perspectives to a Long-Standing Model. Brain Pathol. 2015, 25, 377-390. [CrossRef]

158. Sterner, E.Y.; Kalynchuk, L.E. Behavioral and neurobiological consequences of prolonged glucocorticoid exposure in rats: Relevance to depression. Prog. Neuro-Psychopharmacol. Biol. Psychiatry 2010, 34, 777-790. [CrossRef]

159. Popoli, M.; Yan, Z.; McEwen, B.S.; Sanacora, G. The stressed synapse: The impact of stress and glucocorticoids on glutamate transmission. Nat. Rev. Neurosci. 2012, 13, 22-37. [CrossRef]

160. Zhao, Y.; Lin, Z.; Chen, L.; Ouyang, L.; Gu, L.; Chen, F.; Zhang, Q. Hippocampal astrocyte atrophy in a mouse depression model induced by corticosterone is reversed by fluoxetine instead of benzodiazepine diazepam. Prog. Neuro-Psychopharmacol. Biol. Psychiatry 2018, 83, 99-109. [CrossRef]

161. Weng, L.; Guo, X.; Li, Y.; Yang, X.; Han, Y. Apigenin reverses depression-like behavior induced by chronic corticosterone treatment in mice. Eur. J. Pharmacol. 2016, 774, 50-54. [CrossRef]

162. Ali, S.H.; Madhana, R.M.; Athira, K.V.; Kasala, E.R.; Bodduluru, L.N.; Pitta, S.; Mahareddy, J.R.; Lahkar, M. Resveratrol ameliorates depressive-like behavior in repeated corticosterone-induced depression in mice. Steroids 2015, 101, 37-42. [CrossRef]

163. Fukumoto, K.; Toki, H.; Iijima, M.; Hashihayata, T.; Yamaguchi, J.-I.; Hashimoto, K.; Chaki, S. Antidepressant Potential of (R)-Ketamine in Rodent Models: Comparison with (S)-Ketamine. J. Pharmacol. Exp. Ther. 2017, 361, 9-16. [CrossRef]

164. Solberg, L.C.; Baum, A.E.; Ahmadiyeh, N.; Shimomura, K.; Li, R.; Turek, F.W.; Churchill, G.A.; Takahashi, J.S.; Redei, E.E. Sexand lineage-specific inheritance of depression-like behavior in the rat. Mamm. Genome 2004, 15, 648-662. [CrossRef] [PubMed]

165. Rittenhouse, P.A.; López-Rubalcava, C.; Stanwood, G.D.; Lucki, I. Amplified behavioral and endocrine responses to forced swim stress in the Wistar-Kyoto rat. Psychoneuroendocrinology 2002, 27, 303-318. [CrossRef] 
166. Paré, W.P. Open field, learned helplessness, conditioned defensive burying, and forced-swim tests in WKY rats. Physiol. Behav. 1994, 55, 433-439. [CrossRef]

167. Lu, H.Z.; Zhang, F.X.; Hong, X.W.; Wang, M.Y.; Huang, L.; Zheng, J.; Chen, Y.H. Effect of glucocorticoid receptor function on the behavior of rats with attention deficit hyperactivity disorder. Zhongguo Dang Dai Er Ke Za Zhi 2018, 20, 848-853. [CrossRef]

168. Wright, R.L.; Gilmour, G.; Dwyer, D.M. Wistar Kyoto Rats Display Anhedonia In Consumption but Retain Some Sensitivity to the Anticipation of Palatable Solutions. Front. Behav. Neurosci. 2020, 14, 70. [CrossRef]

169. Redei, E.; Pare, W.P.; Aird, F.; Kluczynski, J. Strain differences in hypothalamic-pituitary-adrenal activity and stress ulcer. Am. J. Physiol. Integr. Comp. Physiol. 1994, 266, R353-R360. [CrossRef]

170. Gómez, F.; Lahmame, A.; De Kloet, E.R.; Armario, A. Hypothalamic-Pituitary-Adrenal Response to Chronic Stress in Five Inbred Rat Strains: Differential Responses Are Mainly Located at the Adrenocortical Level. Neuroendocrinology 1996, 63, 327-337. [CrossRef]

171. Will, C.C.; Aird, F.; Redei, E.E. Selectively bred Wistar-Kyoto rats: An animal model of depression and hyper-responsiveness to antidepressants. Mol. Psychiatry 2003, 8, 925-932. [CrossRef]

172. Shetty, R.A.; Sadananda, M. Brief Social Isolation in the Adolescent Wistar-Kyoto Rat Model of Endogenous Depression Alters Corticosterone and Regional Monoamine Concentrations. Neurochem. Res. 2017, 42, 1470-1477. [CrossRef]

173. Lahmame, A.; Del Arco, C.; Pazos, A.; Yritia, M.; Armario, A. Are Wistar-Kyoto rats a genetic animal model of depression resistant to antidepressants? Eur. J. Pharmacol. 1997, 337, 115-123. [CrossRef]

174. Lahmame, A.; Armario, A. Differential responsiveness of inbred strains of rats to antidepressants in the forced swimming test: Are Wistar Kyoto rats an animal model of subsensitivity to antidepressants? Psychopharmacology 1996, 123, 191-198. [CrossRef] [PubMed]

175. López-Rubalcava, C. Strain Differences in the Behavioral Effects of Antidepressant Drugs in the Rat Forced Swimming Test. Neuropsychopharmacology 2000, 22, 191-199. [CrossRef]

176. Overstreet, D.H.; Janowsky, D.S.; Gillin, J.; Shiromani, P.J.; Sutin, E.L. Stress-induced immobility in rats with cholinergic supersensitivity. Biol. Psychiatry 1986, 21, 657-664. [CrossRef]

177. Yadid, G.; Nakash, R.; Deri, I.; Tamar, G.; Kinor, N.; Gispan, I.; Zangen, A. Elucidation of the neurobiology of depression: Insights from a novel genetic animal model. Prog. Neurobiol. 2000, 62, 353-378. [CrossRef]

178. Wegener, G.; Mathe, A.A.; Neumann, I.D. Selectively Bred Rodents as Models of Depression and Anxiety. In Behavioral Neurobiology of Suicide and Self Harm; Cryan, J.F., Reif, A., Eds.; Springer: Berlin/Heidelberg, Germany, 2011; Volume 12, pp. $139-187$.

179. Badenhorst, N.J.; Brand, L.; Harvey, B.H.; Ellis, S.; Brink, C.B. Long-term effects of pre-pubertal fluoxetine on behaviour and monoaminergic stress response in stress-sensitive rats. Acta Neuropsychiatr. 2016, 29, 222-235. [CrossRef]

180. Nesher, E.; Gross, M.; Lisson, S.; Tikhonov, T.; Yadid, G.; Pinhasov, A. Differential responses to distinct psychotropic agents of selectively bred dominant and submissive animals. Behav. Brain Res. 2013, 236, 225-235. [CrossRef]

181. Gross, M.; Romi, H.; Gilimovich, Y.; Drori, E.; Pinhasov, A. Placental glucocorticoid receptor and 11 $\beta$-hydroxysteroid dehydrogenase-2 recruitment indicates impact of prenatal adversity upon postnatal development in mice. Stress 2018, 21, 474-483. [CrossRef]

182. Gross, M.; Pinhasov, A. Chronic mild stress in submissive mice: Marked polydipsia and social avoidance without hedonic deficit in the sucrose preference test. Behav. Brain Res. 2016, 298, 25-34. [CrossRef]

183. Gross, M.; Romi, H.; Miller, A.; Pinhasov, A. Social dominance predicts hippocampal glucocorticoid receptor recruitment and resilience to prenatal adversity. Sci. Rep. 2018, 8, 1-13. [CrossRef]

184. Gross, M.; Sheinin, A.; Nesher, E.; Tikhonov, T.; Baranes, D.; Pinhasov, A.; Michaelevski, I. Early onset of cognitive impairment is associated with altered synaptic plasticity and enhanced hippocampal GluA1 expression in a mouse model of depression. Neurobiol. Aging 2015, 36, 1938-1952. [CrossRef]

185. Nesher, E.; Koman, I.; Gross, M.; Tikhonov, T.; Bairachnaya, M.; Salmon-Divon, M.; Levin, Y.; Gerlitz, G.; Michaelevski, I.; Yadid, G.; et al. Synapsin IIb as a functional marker of submissive behavior. Sci. Rep. 2015, 5, 10287. [CrossRef] [PubMed]

186. Murlanova, K.; Michaelevski, I.; Kreinin, A.; Terrillion, C.; Pletnikov, M.; Pinhasov, A. Link between temperament traits, brain neurochemistry and response to SSRI: Insights from animal model of social behavior. J. Affect. Disord. 2020. [CrossRef]

187. Weiss, J.M.; Cierpial, M.A.; West, C.H. Selective Breeding of Rats for High and Low Motor Activity in a Swim Test. Pharmacol. Biochem. Behav. 1998, 61, 49-66. [CrossRef]

188. Gutman, D.A.; Coyer, M.J.; Boss-Williams, K.A.; Owens, M.J.; Nemeroff, C.B.; Weiss, J.M. Behavioral effects of the CRF1 receptor antagonist R121919 in rats selectively bred for high and low activity in the swim test. Psychoneuroendocrinology 2008, 33, $1093-1101$. [CrossRef]

189. West, C.H.; Weiss, J.M. Effects of antidepressant drugs on rats bred for low activity in the swim test. Pharmacol. Biochem. Behav. 1998, 61, 67-79. [CrossRef]

190. West, C.H.; Bonsall, R.W.; Emery, M.S.; Weiss, J.M. Rats selectively bred for high and low swim-test activity show differential responses to dopaminergic drugs. Psychopharmacology 1999, 146, 241-251. [CrossRef]

191. West, C.H.; Boss-Williams, K.A.; Weiss, J.M. Motor activation by amphetamine infusion into nucleus accumbens core and shell subregions of rats differentially sensitive to dopaminergic drugs. Behav. Brain Res. 1998, 98, 155-165. [CrossRef] 
192. Tabb, K.D.; Boss-Williams, K.A.; Weiss, J.M.; Weinshenker, D. Rats bred for susceptibility to depression-like phenotypes have higher kainic acid-induced seizure mortality than their depression-resistant counterparts. Epilepsy Res. 2007, 74, 140-146. [CrossRef]

193. Aulakh, C.S.; Hill, J.L.; Murphy, D.L. Attenuation of hypercortisolemia in fawn-hooded rats by antidepressant drugs. Eur. J. Pharmacol. 1993, 240, 85-88. [CrossRef]

194. Overstreet, D.H.; Rezvani, A.H.; Djouma, E.; Parsian, A.; Lawrence, A.J. Depressive-like behavior and high alcohol drinking co-occur in the FH/WJD rat but appear to be under independent genetic control. Neurosci. Biobehav. Rev. 2007, 31, 103-114. [CrossRef]

195. Chen, F.; Rezvani, A.; Jarrott, B.; Lawrence, A.J. Distribution of GABAA receptors in the limbic system of alcohol-preferring and non-preferring rats: In situ hybridisation histochemistry and receptor autoradiography. Neurochem. Int. 1998, 32, 143-151. [CrossRef]

196. Chen, F.; Lawrence, A.J. 5-HT Transporter Sites and 5-HT1A and 5-HT3 Receptors in Fawn-Hooded Rats: A Quantitative Autoradiography Study. Alcohol. Clin. Exp. Res. 2000, 24, 1093-1102. [CrossRef] [PubMed]

197. Aulakh, C.; Tolliver, T.; Wozniak, K.; Hill, J.; Murphy, D. Functional and biochemical evidence for altered serotonergic function in the Fawn-Hooded rat strain. Pharmacol. Biochem. Behav. 1994, 49, 615-620. [CrossRef]

198. Knapp, D.J.; Harper, K.M.; Melton, J.; Breese, G. Comparative effects of stressors on behavioral and neuroimmune responses of fawn-hooded (FH/Wjd) and Wistar rats: Implications for models of depression. J. Neuroimmunol. 2018, 322, 74-80. [CrossRef] [PubMed]

199. Urani, A.; Chourbaji, S.; Gass, P. Mutant mouse models of depression: Candidate genes and current mouse lines. Neurosci. Biobehav. Rev. 2005, 29, 805-828. [CrossRef]

200. Ding, Y.; Dai, J. Advance in Stress for Depressive Disorder. Adv. Exp. Med. Biol. 2019, 1180, 147-178. [CrossRef]

201. Feder, A.; Nestler, E.J.; Charney, D.S. Psychobiology and molecular genetics of resilience. Nat. Rev. Neurosci. 2009, 10, 446-457. [CrossRef]

202. Russo, S.J.; Murrough, J.W.; Han, M.-H.; Charney, D.S.; Nestler, E.J. Neurobiology of resilience. Nat. Neurosci. 2012, 15, 1475-1484. [CrossRef]

203. Morgan, C.A.; Rasmusson, A.M.; Wang, S.; Hoyt, G.; Hauger, R.L.; Hazlett, G. Neuropeptide-Y, cortisol, and subjective distress in humans exposed to acute stress: Replication and extension of previous report. Biol. Psychiatry 2002, 52, 136-142. [CrossRef]

204. McGaugh, J.L. The amygdala modulates the consolidation of memories of emotionally arousing experiences. Annu. Rev. Neurosci. 2004, 27, 1-28. [CrossRef]

205. Charney, D.S. Psychobiological mechanisms of resilience and vulnerability: Implications for successful adaptation to extreme stress. Am. J. Psychiatry 2004, 161, 195-216. [CrossRef] [PubMed]

206. Pope, H.G.; Cohane, G.H.; Kanayama, G.; Siegel, A.J.; Hudson, J.I. Testosterone gel supplementation for men with refractory depression: A randomized, placebo-controlled trial. Am. J. Psychiatry 2003, 160, 105-111. [CrossRef] [PubMed]

207. Kennis, M.; Gerritsen, L.; Van Dalen, M.; Williams, A.; Cuijpers, P.; Bockting, C.L.H. Prospective biomarkers of major depressive disorder: A systematic review and meta-analysis. Mol. Psychiatry 2020, 25, 321-338. [CrossRef] [PubMed]

208. Nandam, L.S.; Brazel, M.; Zhou, M.; Jhaveri, D.J. Cortisol and major depressive disorder-Translating findings from humans to animal models and back. Front. Psychiatry 2020, 10, 974. [CrossRef]

209. Chen, Y.; Baram, T.Z. Toward understanding how early-life stress reprograms cognitive and emotional brain networks. Neuropsychopharmacology 2016, 41, 197-206. [CrossRef]

210. Nagy, C.; Turecki, G. Sensitive periods in epigenetics: Bringing us closer to complex behavioral phenotypes. Epigenomics 2012, 4, 445-457. [CrossRef]

211. Casey, B.J.; Jones, R.M. Neurobiology of the adolescent brain and behavior: Implications for substance use disorders. J. Am. Acad. Child Adolesc. Psychiatry 2010, 49, 1189-1201. [CrossRef]

212. Bagot, R.C.; Labonté, B.; Peña, C.J.; Nestler, E.J. Epigenetic signaling in psychiatric disorders: Stress and depression. Dialog. Clin. Neurosci. 2014, 16, 281-295. [CrossRef]

213. Kessler, R.C.; Berglund, P.; Demler, O.; Jin, R.; Merikangas, K.R.; Walters, E.E. Lifetime prevalence and age-of-onset distributions of dsm-iv disorders in the national comorbidity survey replication. Arch. Gen. Psychiatry 2005, 62, 593-602. [CrossRef]

214. Odonnel, K.; Glover, V.; Barker, E.D.; O'Connor, T.G. The persisting effect of maternal mood in pregnancy on childhood psychopathology. Dev. Psychopathol. 2014, 26, 393-403. [CrossRef]

215. Maxwell, S.D.; Fineberg, A.M.; Drabick, D.A.G.; Murphy, S.K.; Ellman, L.M.; Murphy, S.K. Maternal prenatal stress and other developmental risk factors for adolescent depression: Spotlight on sex differences. J. Abnorm. Child Psychol. 2018, 46, 381-397. [CrossRef] [PubMed]

216. Brannigan, R.; Cannon, M.; Tanskanen, A.; Huttunen, M.O.; Leacy, F.P.; Clarke, M.C. The association between subjective maternal stress during pregnancy and offspring clinically diagnosed psychiatric disorders. Acta Psychiatr. Scand. 2019, 139, 304-310. [CrossRef] [PubMed]

217. Howland, M.A.; Sandman, C.A.; Glynn, L.M. Developmental origins of the human hypothalamic-pituitary-adrenal axis. Expert Rev. Endocrinol. Metab. 2017, 12, 321-339. [CrossRef] [PubMed] 
218. Bock, J.; Murmu, M.S.; Biala, Y.; Weinstock, M.; Braun, K. Prenatal stress and neonatal handling induce sex-specific changes in dendritic complexity and dendritic spine density in hippocampal subregions of prepubertal rats. Neuroscience 2011, 193, 34-43. [CrossRef] [PubMed]

219. Baratta, A.M.; Kanyuch, N.; Cole, C.; Valafar, H.; DesLauriers, J.; Pocivavsek, A. Acute sleep deprivation during pregnancy in rats: Rapid elevation of placental and fetal inflammation and kynurenic acid. Neurobiol. Stress 2020, 12, 100204. [CrossRef] [PubMed]

220. Weinstock, M. Prenatal stressors in rodents: Effects on behavior. Neurobiol. Stress 2017, 6, 3-13. [CrossRef] [PubMed]

221. Sickmann, H.M.; Arentzen, T.S.; Dyrby, T.B.; Plath, N.; Kristensen, M.P. Prenatal stress produces sex-specific changes in depression-like behavior in rats: Implications for increased vulnerability in females. J. Dev. Orig. Health Dis. 2015, 6, $462-474$. [CrossRef]

222. Mychasiuk, R.; Gibb, R.; Kolb, B. Prenatal stress alters dendritic morphology and synaptic connectivity in the prefrontal cortex and hippocampus of developing offspring. Synapse 2011, 66, 308-314. [CrossRef]

223. Murmu, M.S.; Salomon, S.; Biala, Y.; Weinstock, M.; Braun, K.; Bock, J. Changes of spine density and dendritic complexity in the prefrontal cortex in offspring of mothers exposed to stress during pregnancy. Eur. J. Neurosci. 2006, 24, 1477-1487. [CrossRef]

224. Claessens, S.E.F.; Daskalakis, N.P.; Van Der Veen, R.; Oitzl, M.S.; De Kloet, E.R.; Champagne, D.L. Development of individual differences in stress responsiveness: An overview of factors mediating the outcome of early life experiences. Psychopharmacology 2011, 214, 141-154. [CrossRef]

225. Cirulli, F.; Francia, N.; Berry, A.; Aloe, L.; Alleva, E.; Suomi, S.J. Early life stress as a risk factor for mental health: Role of neurotrophins from rodents to non-human primates. Neurosci. Biobehav. Rev. 2009, 33, 573-585. [CrossRef] [PubMed]

226. Maestripieri, D. Early experience affects the intergenerational transmission of infant abuse in rhesus monkeys. Proc. Natl. Acad. Sci. USA 2005, 102, 9726-9729. [CrossRef] [PubMed]

227. Bebbington, P.; Bhugra, D.; Brugha, T.; Singleton, N.; Farrell, M.; Jenkins, R.; Lewis, G.; Meltzer, H. Psychosis, victimisation and childhood disadvantage. Br. J. Psychiatry 2004, 185, 220-226. [CrossRef] [PubMed]

228. Kendler, K.S.; Kessler, R.C.; Walters, E.E.; MacLean, C.; Neale, M.C.; Heath, A.C.; Eaves, L.J. Stressful life events, genetic liability, and onset of an episode of major depression in women. Am. J. Psychiatry 1995, 152, 833-842. [CrossRef]

229. Own, L.S.; Patel, P.D. Maternal behavior and offspring resiliency to maternal separation in c57bl/6 mice. Horm. Behav. 2013, 63, 411-417. [CrossRef]

230. Savignac, H.M.; Dinan, T.G.; Cryan, J.F. Resistance to early-life stress in mice: Effects of genetic background and stress duration. Front. Behav. Neurosci. 2011, 5, 13. [CrossRef]

231. Sisk, C.L.; Foster, D.L. The neural basis of puberty and adolescence. Nat. Neurosci. 2004, 7, 1040-1047. [CrossRef]

232. Kessler, R.C.; Berglund, P.; Demler, O.; Jin, R.; Koretz, D.; Merikangas, K.R.; Rush, A.J.; Walters, E.E.; Wang, P.S. The Epidemiology of Major Depressive Disorder. JAMA 2003, 289, 3095-3105. [CrossRef]

233. McCormick, C.M.; Green, M.R.; Simone, J.J. Translational relevance of rodent models of hypothalamic-pituitary-adrenal function and stressors in adolescence. Neurobiol. Stress 2017, 6, 31-43. [CrossRef]

234. Yorgason, J.T.; Calipari, E.S.; Ferris, M.J.; Karkhanis, A.N.; Fordahl, S.; Weiner, J.L.; Jones, S.R. Social isolation rearing increases dopamine uptake and psychostimulant potency in the striatum. Neuropharmacology 2016, 101, 471-479. [CrossRef]

235. Holson, R.; Scallet, A.; Ali, S.; Turner, B. “Isolation stress” revisited: Isolation-rearing effects depend on animal care methods. Physiol. Behav. 1991, 49, 1107-1118. [CrossRef]

236. Wright, I.K.; Upton, N.; Marsden, C. Resocialisation of isolation-reared rats does not alter their anxiogenic profile on the elevated X-maze model of anxiety. Physiol. Behav. 1991, 50, 1129-1132. [CrossRef]

237. Weintraub, A.; Singaravelu, J.; Bhatnagar, S. Enduring and sex-specific effects of adolescent social isolation in rats on adult stress reactivity. Brain Res. 2010, 1343, 83-92. [CrossRef] [PubMed]

238. Jahng, J.W.; Yoo, S.B.; Ryu, V.; Lee, J.-H. Hyperphagia and depression-like behavior by adolescence social isolation in female rats. Int. J. Dev. Neurosci. 2012, 30, 47-53. [CrossRef] [PubMed]

239. Kuramochi, M.; Nakamura, S. Effects of postnatal isolation rearing and antidepressant treatment on the density of serotonergic and noradrenergic axons and depressive behavior in rats. Neuroscience 2009, 163, 448-455. [CrossRef]

240. Ikemoto, S.; Panksepp, J. The effects of early social isolation on the motivation for social play in juvenile rats. Dev. Psychobiol. 1992, 25, 261-274. [CrossRef]

241. Toth, M.; Mikics, E.; Tulogdi, A.; Aliczki, M.; Haller, J. Post-weaning social isolation induces abnormal forms of aggression in conjunction with increased glucocorticoid and autonomic stress responses. Horm. Behav. 2011, 60, 28-36. [CrossRef]

242. Lopez, M.F.; Laber, K. Impact of social isolation and enriched environment during adolescence on voluntary ethanol intake and anxiety in C57BL/6J mice. Physiol. Behav. 2015, 148, 151-156. [CrossRef]

243. Harvey, B.H.; Regenass, W.; Dreyer, W.; Möller, M. Social isolation rearing-induced anxiety and response to agomelatine in male and female rats: Role of corticosterone, oxytocin, and vasopressin. J. Psychopharmacol. 2019, 33, 640-646. [CrossRef]

244. Whitaker, L.R.; Degoulet, M.; Morikawa, H. Social Deprivation Enhances VTA Synaptic Plasticity and Drug-Induced Contextual Learning. Neuron 2013, 77, 335-345. [CrossRef]

245. Brenes, J.C.; Rodríguez, O.; Fornaguera-Trías, J. Differential effect of environment enrichment and social isolation on depressivelike behavior, spontaneous activity and serotonin and norepinephrine concentration in prefrontal cortex and ventral striatum. Pharmacol. Biochem. Behav. 2008, 89, 85-93. [CrossRef] [PubMed]

246. Seligman, M.E.; Maier, S.F. Failure to escape traumatic shock. J. Exp. Psychol. 1967, 74, 1-9. [CrossRef] [PubMed] 
247. Chourbaji, S.; Zacher, C.; Sanchis-Segura, C.; Dormann, C.; Vollmayr, B.; Gass, P. Learned helplessness: Validity and reliability of depressive-like states in mice. Brain Res. Protoc. 2005, 16, 70-78. [CrossRef] [PubMed]

248. Landgraf, D.; Long, J.; Der-Avakian, A.; Streets, M.; Welsh, D.K. Dissociation of Learned Helplessness and Fear Conditioning in Mice: A Mouse Model of Depression. PLoS ONE 2015, 10, e0125892. [CrossRef]

249. Seligman, M.E.; Beagley, G. Learned helplessness in the rat. J. Comp. Physiol. Psychol. 1975, 88, 534-541. [CrossRef]

250. Pryce, C.R.; Azzinnari, D.; Sigrist, H.; Gschwind, T.; Lesch, K.-P.; Seifritz, E. Establishing a learned-helplessness effect paradigm in C57BL/ 6 mice: Behavioural evidence for emotional, motivational and cognitive effects of aversive uncontrollability per se. Neuropharmacology 2012, 62, 358-372. [CrossRef]

251. Maier, S.F.; Seligman, M.E.P. Learned helplessness at fifty: Insights from neuroscience. Psychol. Rev. 2016, 123, 349-367. [CrossRef]

252. Cheng, Y.; Desse, S.; Martinez, A.; Worthen, R.J.; Jope, R.S.; Beurel, E. TNF $\alpha$ disrupts blood brain barrier integrity to maintain prolonged depressive-like behavior in mice. Brain Behav. Immun. 2018, 69, 556-567. [CrossRef]

253. Cheng, Y.; Jope, R.S.; Beurel, E. A pre-conditioning stress accelerates increases in mouse plasma inflammatory cytokines induced by stress. BMC Neurosci. 2015, 16, 1-8. [CrossRef]

254. Golden, S.A.; Iii, H.E.C.; Berton, O.; Russo, S.J. A standardized protocol for repeated social defeat stress in mice. Nat. Protoc. 2011, 6, 1183-1191. [CrossRef]

255. Schloesser, R.J.; Lehmann, M.; Martinowich, K.; Manji, H.K.; Herkenham, M. Environmental enrichment requires adult neurogenesis to facilitate the recovery from psychosocial stress. Mol. Psychiatry 2010, 15, 1152-1163. [CrossRef] [PubMed]

256. Lehmann, M.L.; Herkenham, M. Environmental Enrichment Confers Stress Resiliency to Social Defeat through an Infralimbic Cortex-Dependent Neuroanatomical Pathway. J. Neurosci. 2011, 31, 6159-6173. [CrossRef] [PubMed]

257. Yohn, C.N.; Ashamalla, S.A.; Bokka, L.; Gergues, M.M.; Garino, A.; Samuels, B.A. Social instability is an effective chronic stress paradigm for both male and female mice. Neuropharmacology 2019, 160, 107780. [CrossRef] [PubMed]

258. Lombion-Pouthier, S.; Vandel, P.; Nezelof, S.; Haffen, E.; Millot, J.-L. Odor perception in patients with mood disorders. J. Affect. Disord. 2006, 90, 187-191. [CrossRef]

259. Pause, B.M.; Miranda, A.; Göder, R.; Aldenhoff, J.B.; Ferstl, R. Reduced olfactory performance in patients with major depression. J. Psychiatr. Res. 2001, 35, 271-277. [CrossRef]

260. Negoias, S.; Croy, I.; Gerber, J.; Puschmann, S.; Petrowski, K.; Joraschky, P.; Hummel, T. Reduced olfactory bulb volume and olfactory sensitivity in patients with acute major depression. Neuroscience 2010, 169, 415-421. [CrossRef]

261. Aleksandrova, I.Y.; Kuvichkin, V.V.; Kashparov, I.A.; Medvinskaya, N.I.; Nesterova, I.V.; Lunin, S.; Samokhin, A.; Bobkova, N.V. Increased Level of $\beta$-Amyloid in the Brain of Bulbectomized Mice. Biochemistry 2004, 69, 176-180. [CrossRef]

262. Bobkova, N.; Vorobyov, V.; Medvinskaya, N.; Nesterova, I.; Tatarnikova, O.; Nekrasov, P.; Samokhin, A.; Deev, A.; Sengpiel, F.; Koroev, D.; et al. Immunization Against Specific Fragments of Neurotrophin p75 Receptor Protects Forebrain Cholinergic Neurons in the Olfactory Bulbectomized Mice. J. Alzheimer's Dis. 2016, 53, 289-301. [CrossRef]

263. Van Laeken, N.; Pauwelyn, G.; Dockx, R.; Descamps, B.; Brans, B.; Peremans, K.; Baeken, C.; Goethals, I.; Vanhove, C.; De Vos, F. Regional alterations of cerebral [18F]FDG metabolism in the chronic unpredictable mild stress- and the repeated corticosterone depression model in rats. J. Neural Transm. 2018, 125, 1381-1393. [CrossRef]

264. Mileva, G.R.; Rooke, J.; Ismail, N.; Bielajew, C. Corticosterone and immune cytokine characterization following environmental manipulation in female WKY rats. Behav. Brain Res. 2017, 316, 197-204. [CrossRef]

265. Russell, R.W.; Overstreet, D.H. Mechanisms underlying sensitivity to organophosphorus anticholinesterase compounds. Prog. Neurobiol. 1987, 28, 97-129. [CrossRef]

266. Overstreet, D.H.; Russell, R.W.; Crocker, A.D.; Schiller, G.D. Selective breeding for differences in cholinergic function: Pre- and postsynaptic mechanisms involved in sensitivity to the anticholinesterase, DFP. Brain Res. 1984, 294, 327-332. [CrossRef]

267. Janowsky, D.S.; Overstreet, D.H.; Nurnberger, J.I. Is cholinergic sensitivity a genetic marker for the affective disorders? Am. J. Med. Genet. 1994, 54, 335-344. [CrossRef] [PubMed]

268. Jindal, R.D.; Thase, M.E.; Fasiczka, A.L.; Friedman, E.S.; Buysse, D.J.; Frank, E.; Kupfer, D.J. Electroencephalographic sleep profiles in single-episode and recurrent unipolar forms of major depression: II. comparison during remission. Biol. Psychiatry 2002, 51, 230-236. [CrossRef]

269. Pucilowski, O.; Overstreet, D.H.; Rezvani, A.H.; Janowsky, D.S. Chronic mild stress-induced anhedonia: Greater effect in a genetic rat model of depression. Physiol. Behav. 1993, 54, 1215-1220. [CrossRef]

270. Feder, Y.; Nesher, E.; Ogran, A.; Kreinin, A.; Malatynska, E.; Yadid, G.; Pinhasov, A. Selective breeding for dominant and submissive behavior in Sabra mice. J. Affect. Disord. 2010, 126, 214-222. [CrossRef]

271. Nesher, E.; Peskov, V.; Rylova, A.; Raz, O.; Pinhasov, A. Comparative Analysis of the Behavioral and Biomolecular Parameters of Four Mouse Strains. J. Mol. Neurosci. 2012, 46, 276-284. [CrossRef]

272. Borovok, N.; Nesher, E.; Reichenstein, M.; Tikhonova, T.; Levin, Y.; Pinhasov, A.; Michaelevski, I. Effect of social interactions on hippocampal protein expression in animal dominant and submissive model of behavioral disorders. Proteom. Clin. Appl. 2017, 11, 264. [CrossRef]

273. Bairachnaya, M.; Agranyoni, O.; Antoch, M.; Michaelevski, I.; Pinhasov, A. Innate sensitivity to stress facilitates inflammation, alters metabolism and shortens lifespan in a mouse model of social hierarchy. Aging 2019, 11, 9901-9911. [CrossRef] 
274. Weiss, J.M.; West, C.; Emery, M.; Bonsall, R.; Moore, J.; Boss-Williams, K. Rats selectively-bred for behavior related to affective disorders: Proclivity for intake of alcohol and drugs of abuse, and measures of brain monoamines. Biochem. Pharmacol. 2008, 75, 134-159. [CrossRef]

275. Guénet, J.L. The mouse genome. Genome Res. 2005, 15, 1729-1740. [CrossRef] [PubMed]

276. Sullivan, P.F.; Neale, M.; Kendler, K.S. Genetic Epidemiology of Major Depression: Review and Meta-Analysis. Am. J. Psychiatry 2000, 157, 1552-1562. [CrossRef] [PubMed]

277. Bregman, T.; Nona, C.; Volle, J.; Diwan, M.; Raymond, R.; Fletcher, P.J.; Nobrega, J.N.; Hamani, C. Deep brain stimulation induces antidepressant-like effects in serotonin transporter knockout mice. Brain Stimul. 2018, 11, 423-425. [CrossRef] [PubMed]

278. Kraus, C.; Castrén, E.; Kasper, S.; Lanzenberger, R. Serotonin and neuroplasticity-Links between molecular, functional and structural pathophysiology in depression. Neurosci. Biobehav. Rev. 2017, 77, 317-326. [CrossRef] [PubMed]

279. Dell'Osso, L.; Carmassi, C.; Mucci, F.; Marazziti, D. Depression, Serotonin and Tryptophan. Curr. Pharm. Des. 2016, 22, 949-954. [CrossRef] [PubMed]

280. Finnell, J.E.; Moffitt, C.M.; Hesser, L.A.; Harrington, E.; Melson, M.N.; Wood, C.S.; Wood, S.K. The contribution of the locus coeruleus-norepinephrine system in the emergence of defeat-induced inflammatory priming. Brain Behav. Immun. 2019, 79, 102-113. [CrossRef] [PubMed]

281. Liu, Y.; Zhao, J.; Guo, W. Emotional Roles of Mono-Aminergic Neurotransmitters in Major Depressive Disorder and Anxiety Disorders. Front. Psychol. 2018, 9, 2201. [CrossRef]

282. Gainetdinov, R.R. Dopamine transporter mutant mice in experimental neuropharmacology. Naunyn-Schmiedeberg's Arch. Pharmacol. 2008, 377, 301-313. [CrossRef]

283. Felger, J.C. The Role of Dopamine in Inflammation-Associated Depression: Mechanisms and Therapeutic Implications. Curr. Top. Behav. Neurosci. 2016, 31, 199-219. [CrossRef]

284. Belujon, P.; Grace, A.A. Dopamine System Dysregulation in Major Depressive Disorders. Int. J. Neuropsychopharmacol. 2017, 20, 1036-1046. [CrossRef]

285. Yohn, C.N.; Gergues, M.M.; Samuels, B.A. The role of 5-HT receptors in depression. Mol. Brain 2017, 10, 28. [CrossRef] [PubMed]

286. Lu, G.; Li, J.; Zhang, H.; Zhao, X.; Yan, L.-J.; Yang, X. Role and Possible Mechanisms of Sirt1 in Depression. Oxidative Med. Cell. Longev. 2018, 2018, 8596903. [CrossRef] [PubMed]

287. Cai, N.; Bigdeli, T.B.; Kretzschmar, W.; Li, Y.; Liang, J.; Song, L.; Hu, J.; Li, Q.; Jin, W.; Hu, Z.; et al. Sparse whole-genome sequencing identifies two loci for major depressive disorder. Nat. Cell Biol. 2015, 523, 588-591. [CrossRef]

288. Li, X.; Luo, Z.; Gu, C.; Hall, L.S.; McIntosh, A.M.; Zeng, Y.; Porteous, D.J.; Hayward, C.; Li, M.; the 23andMe Research Team7; et al. Common variants on 6q16.2, 12q24.31 and 16p13.3 are associated with major depressive disorder. Neuropsychopharmacology 2018, 43, 2146-2153. [CrossRef] [PubMed]

289. Meier, S.M.; Trontti, K.; Purves, K.L.; Als, T.D.; Grove, J.; Laine, M.; Pedersen, M.G.; Bybjerg-Grauholm, J.; Bækved-Hansen, M.; Sokolowska, E.; et al. Genetic Variants Associated With Anxiety and Stress-Related Disorders. JAMA Psychiatry 2019, 76, 924-932. [CrossRef] [PubMed]

290. Barkus, C. Genetic Mouse Models of Depression. Curr. Top. Behav. Neurosci. 2013, 14, 55-78. [CrossRef] [PubMed]

291. Haenisch, B.; Bönisch, H. Depression and antidepressants: Insights from knockout of dopamine, serotonin or noradrenaline re-uptake transporters. Pharmacol. Ther. 2011, 129, 352-368. [CrossRef]

292. Lira, A.; Zhou, M.; Castanon, N.; Ansorge, M.S.; Gordon, J.A.; Francis, J.H.; Bradley-Moore, M.; Lira, J.; Underwood, M.D.; Arango, V.; et al. Altered depression-related behaviors and functional changes in the dorsal raphe nucleus of serotonin transporter-deficient mice. Biol. Psychiatry 2003, 54, 960-971. [CrossRef]

293. Holmes, A.; Murphy, D.L.; Crawley, J.N. Abnormal behavioral phenotypes of serotonin transporter knockout mice: Parallels with human anxiety and depression. Biol. Psychiatry 2003, 54, 953-959. [CrossRef]

294. Bengel, D.; Murphy, D.L.; Andrews, A.M.; Wichems, C.H.; Feltner, D.; Heils, A.; Mössner, R.; Westphal, H.; Lesch, K.-P. Altered Brain Serotonin Homeostasis and Locomotor Insensitivity to 3,4-Methylenedioxymethamphetamine ("Ecstasy") in Serotonin Transporter-Deficient Mice. Mol. Pharmacol. 1998, 53, 649-655. [CrossRef]

295. Kalueff, A.; Da Olivier, J.; Nonkes, L.; Homberg, J.R. Conserved role for the serotonin transporter gene in rat and mouse neurobehavioral endophenotypes. Neurosci. Biobehav. Rev. 2010, 34, 373-386. [CrossRef] [PubMed]

296. Spielewoy, C.; Roubert, C.; Hamon, M.; Nosten-Bertrand, M.; Betancur, C.; Giros, B. Behavioural disturbances associated with hyperdopaminergia in dopamine-transporter knockout mice. Behav. Pharmacol. 2000, 11, 279-290. [CrossRef] [PubMed]

297. Perona, M.T.; Waters, S.; Hall, F.S.; Sora, I.; Lesch, K.-P.; Murphy, D.L.; Caron, M.; Uhl, G.R. Animal models of depression in dopamine, serotonin, and norepinephrine transporter knockout mice: Prominent effects of dopamine transporter deletions. Behav. Pharmacol. 2008, 19, 566-574. [CrossRef] [PubMed]

298. Ide, S.; Ikekubo, Y.; Hua, J.; Takamatsu, Y.; Uhl, G.R.; Sora, I.; Ikeda, K. Reward-enhancing effect of methylphenidate is abolished in dopamine transporter knockout mice: A model of attention-deficit/hyperactivity disorder. Neuropsychopharmacol. Rep. 2018, 38, 149-153. [CrossRef]

299. Leo, D.; Gainetdinov, R.R. Transgenic mouse models for ADHD. Cell Tissue Res. 2013, 354, 259-271. [CrossRef] [PubMed]

300. Jennings, K.A.; Loder, M.K.; Sheward, W.J.; Pei, Q.; Deacon, R.M.J.; Benson, M.A.; Olverman, H.J.; Hastie, N.D.; Harmar, A.J.; Shen, S.; et al. Increased Expression of the 5-HT Transporter Confers a Low- Anxiety Phenotype Linked to Decreased 5-HT Transmission. J. Neurosci. 2006, 26, 8955-8964. [CrossRef] 
301. Catches, J.S.; Xu, J.; Contractor, A. Genetic ablation of the GluK4 kainate receptor subunit causes anxiolytic and antidepressant-like behavior in mice. Behav. Brain Res. 2012, 228, 406-414. [CrossRef]

302. Ernfors, P.; Lee, K.-F.; Jaenisch, R. Mice lacking brain-derived neurotrophic factor develop with sensory deficits. Nat. Cell Biol. 1994, 368, 147-150. [CrossRef]

303. Conover, J.C.; Erickson, J.T.; Katz, D.M.; Bianchi, L.M.; Poueymirou, W.T.; McClain, J.; Pan, L.; Helgren, M.; Ip, N.Y.; Boland, P.; et al. Neuronal deficits, not involving motor neurons, in mice lacking BDNF and/or NT4. Nat. Cell Biol. 1995, 375, 235-238. [CrossRef]

304. Klein, R.; Smeyne, R.J.; Wurst, W.; Long, L.K.; Auerbach, B.A.; Joyner, A.L.; Barbacid, M. Targeted disruption of the trkB neurotrophin receptor gene results in nervous system lesions and neonatal death. Cell 1993, 75, 113-122. [CrossRef]

305. Chourbaji, S.; Hellweg, R.; Brandis, D.; Zörner, B.; Zacher, C.; Lang, U.E.; Henn, F.A.; Hörtnagl, H.; Gass, P. Mice with reduced brain-derived neurotrophic factor expression show decreased choline acetyltransferase activity, but regular brain monoamine levels and unaltered emotional behavior. Mol. Brain Res. 2004, 121, 28-36. [CrossRef] [PubMed]

306. MacQueen, G.M.; Ramakrishman, K.; Croll, S.D.; Siuciak, J.A.; Yu, G.; Young, T.; Fahnestock, M. Performance of heterozygous brain-derived neurotrophic factor knockout mice on behavioral analogues of anxiety, nociception, and depression. Behav. Neurosci. 2001, 115, 1145-1153. [CrossRef] [PubMed]

307. Zörner, B.; Wolfer, D.P.; Brandis, D.; Kretz, O.; Zacher, C.; Madani, R.; Grunwald, I.; Lipp, H.-P.; Klein, R.; Henn, F.A.; et al. Forebrain-specific trkB-receptor knockout mice: Behaviorally more hyperactive than "depressive". Biol. Psychiatry 2003, 54, 972-982. [CrossRef]

308. Groenink, L.; Pattij, T.; De Jongh, R.; Van Der Gugten, J.; Oosting, R.S.; Dirks, A.; Olivier, B. 5-HT1A receptor knockout mice and mice overexpressing corticotropin-releasing hormone in models of anxiety. Eur. J. Pharmacol. 2003, 463, 185-197. [CrossRef]

309. Van Gaalen, M.M.; Stenzel-Poore, M.P.; Holsboer, F.; Steckler, T. Effects of transgenic overproduction of CRH on anxiety-like behaviour. Eur. J. Neurosci. 2002, 15, 2007-2015. [CrossRef]

310. Muglia, L.J.; Jacobson, L.; Dikkes, P.; Majzoub, J.A. Corticotropin-releasing hormone deficiency reveals major fetal but not adult glucocorticoid need. Nat. Cell Biol. 1995, 373, 427-432. [CrossRef]

311. Stuber, G.D.; Stamatakis, A.M.; Kantak, P.A. Considerations When Using Cre-Driver Rodent Lines for Studying Ventral Tegmental Area Circuitry. Neuron 2015, 85, 439-445. [CrossRef]

312. Minichiello, L.; Korte, M.; Wolfer, D.; Kühn, R.; Unsicker, K.; Cestari, V.; Rossi-Arnaud, C.; Lipp, H.-P.; Bonhoeffer, T.; Klein, R. Essential Role for TrkB Receptors in Hippocampus-Mediated Learning. Neuron 1999, 24, 401-414. [CrossRef]

313. Liu, G.; Wang, Y.; Zheng, W.; Cheng, H.; Zhou, R. P11 Loss-of-Function is Associated with Decreased Cell Proliferation and Neurobehavioral Disorders in Mice. Int. J. Biol. Sci. 2019, 15, 1383-1395. [CrossRef]

314. Hebras, J.; Marty, V.; Personnaz, J.; Mercier, P.; Krogh, N.; Nielsen, H.; Aguirrebengoa, M.; Seitz, H.; Pradere, J.-P.; Guiard, B.P.; et al. Reassessment of the involvement of Snord115 in the serotonin 2c receptor pathway in a genetically relevant mouse model. eLife 2020, 9, e60862. [CrossRef]

315. Darvish-Ghane, S.; Quintana, C.; Beaulieu, J.; Martin, L. D1 receptors in the anterior cingulate cortex modulate basal mechanical sensitivity threshold and glutamatergic synaptic transmission. Mol. Brain 2020, 13, 1-15. [CrossRef] [PubMed]

316. Worlein, J.M. Nonhuman Primate Models of Depression: Effects of Early Experience and Stress. ILAR J. 2014, 55, 259-273. [CrossRef] [PubMed]

317. Hennessy, M.B.; McCowan, B.; Jiang, J.; Capitanio, J.P. Depressive-like behavioral response of adult male rhesus monkeys during routine animal husbandry procedure. Front. Behav. Neurosci. 2014, 8, 309. [CrossRef] [PubMed]

318. Xu, F.; Wu, Q.; Xie, L.; Gong, W.; Zhang, J.; Zheng, P.; Zhou, Q.; Jianguo, Z.; Wang, T.; Li, X.; et al. Macaques Exhibit a Naturally-Occurring Depression Similar to Humans. Sci. Rep. 2015, 5, 9220. [CrossRef] [PubMed] 